University of California, Hastings College of the Law UC Hastings Scholarship Repository

Faculty Scholarship

1992

\title{
Judicial Federalism in Action: Coordination of Litigation in State and Federal Courts
}

\author{
William W. Schwarzer \\ UC Hastings College of the Law, schwarzw@uchastings.edu
}

Nancy E. Weiss

Alan Hirsch

Follow this and additional works at: http://repository.uchastings.edu/faculty_scholarship

Part of the Courts Commons

\section{Recommended Citation}

William W. Schwarzer, Nancy E. Weiss, and Alan Hirsch, Judicial Federalism in Action: Coordination of Litigation in State and Federal Courts, 78 Va. L. Rev. 1689 (1992).

Available at: http://repository.uchastings.edu/faculty_scholarship/739 


\section{Faculty Publications \\ UC Hastings College of the Law Library}

Author: William W. Schwarzer

Source: Virginia Law Review

Citation: $\quad 78$ Va. L. Rev. 1689 (1992).

Title: Judicial Federalism in Action: Coordination of Litigation in State and Federal Courts

Originally published in VIRGINIA LAW REVIEW. This article is reprinted with permission from VIRGINIA LAW REVIEW and University of Virginia School of Law. 


\title{
JUDICIAL FEDERALISM IN ACTION: COORDINATION OF LITIGATION IN STATE AND FEDERAL COURTS
}

\author{
William W Schwarzer* \\ Nancy E. Weiss** \\ Alan Hirsch ***
}

Stories are an old way of organizing knowledge, but their place in the world has been less visible since the rise of scientific philosophy during the Enlightenment. Theories about . . . the way gases respond to heat and pressure were provable, always correct, and often simple. Even outside the sciences, the paradigm for truth was that it should be lawlike, preferably reduced to the form of a solvable equation. However, since complexity has emerged as a driving force in the way the world works, the dominant belief in a deterministic and reliably quantifiable truth has begun to yield. There are now many ways of knowing. Our need for realism and proof is as strong, but we can find and express that in this different way. If the planners of Three Mile Island had written a story about how things could go wrong, instead of a numeric analysis of possible fault sequences, they would have been better prepared for the surprise they actually encountered when their complex machine went astray.

Peter Schwartz ${ }^{1}$

\section{INTRODUCTION}

7 HOUGH legal scholarship does not traditionally come in the form of stories, much can be learned from them. ${ }^{2}$ This Article tells the stories of how several state and federal judges forged into uncharted territory to coor-

* Director, Federal Judicial Center; Senior United States District Judge, Northern District of California.

** Associate, Williams \& Connolly, Washington, D.C. Law clerk to Judge William W Schwarzer, 1991-92.

*** Senior Attorney/Writer, Federal Judicial Center.

The authors thank the nuany judges and attorneys who consented to be interviewed and gave generously of their time. The transcripts of these interviews, as well as any reports and other communications cited without specific reference, are on file at the Federal Judicial Center in Washington, D.C.

1 Peter Schwartz, The Art of the Long View 40-41 (1991).

2 See Kin1 L. Scheppele, Foreword: Telling Stories, 87 Mich. L. Rcv. 2073, 2073 (1989) (considering the rise of stories as "an important and recurring theme in legal scholarship"). 
dinate complex litigation pending in their courts. These stories offer a cornucopia of ideas and lessons for botll judges and lawyers. Because each incident of hitigation is sui generis, lowever, awareness of what has been done is only a start. We hope tliese stories will stimulate creative thinking, and encourage a willingness to be innovative and bold that can be apphed in smaller mnltiforum litigation as well as in "monster" cases.

The proliferation of closely related cases spanning multiple forums, botl state and federal, has created serious problems for the civil litigation process and confronted the judiciary with a management crisis. ${ }^{3}$ This type of litigation occurs when numerous claims arise from a single event, sucli as a fire or plane crash, or from a common course of conduct or set of circumstances, sucl as widespread use of a dangerous product or exposure to a toxic substance. When companion cases proceed separately in state and federal courts, duphication and a consequent drain on judicial and private resources resnlt. This, in turn, frustrates the oft-stated goal of the judiciary: "the just, speedy, and inexpensive" resolution of every action. ${ }^{4}$

Within both the state and federal systems, the proeedures available for aggregating or consolidating ${ }^{5}$ claims are limited, but procedures for intersystem aggregation ${ }^{6}$ are even more limited. Altliougl several proposals designed to facilitate intersystem aggregation have been advanced, insufficient attention has been given to the extensive coordination between state and federal courts that can be achieved without new legislation or rules, and witllout subordinating one system to the otller. In a number of cases, state and federal judges have engaged in informal arrangements to coordinate related hitigation. Their cooperation has involved calendar coordination, coordinated discovery, joint settlement efforts, and joint motions hearings and rulings. Some judges have even contemplated joint state-federal trials.

In this Article, we examine several cases in whicl judges have gone beyond existing formal mechanisms to coordinate hitigation in state and federal courts. We describe the various arrangements the judges used to address the problems presented by related inultiforum litigation and consider the circumstances under which coordination is likely to be successful. Finally, we address soine federalisin ${ }^{7}$ concerns that may arise when state and federal judges coordinate litigation.

3 See infra notes 9-15 and accoinpanying text.

4 See, e.g., Fed. R. Civ. P. 1 ("These rules ... shall be construed to secure the just, speedy, and inexpensive determination of every action.").

$s$ "Aggregation" refers to cases being brought onto the same docket, whercas "consolidation" refers to cases being jointly tried or managed.

6 "Intersystem aggregation" refers to the aggregation of state and federal cases.

7 We use the term "federalism" broadly to refer to state and federal interests and the interaction between the two. 
Part I discusses the negative consequences of related multiforum hitigation, and briefly outlines existing formal mechanisms for aggregating cases concurrently pending in both state and federal courts. Part II discusses several proposed new inechanisms for facilitating aggregation. Part III tells the stories of judges who engaged in informal intersystem coordination, including the different ways they went about coordinating their litigation, the techmiques they developed, the procedures that proved most successful, and how difficulties encountered in the process were or were not resolved. Finally, Part IV addresses various issues relevant to state-federal coordination, mcluding the factors that inake a particular hitigation suitable for coordination, the role of attorneys in facilitating coordination, and a variety of federalism concerns-such as deference by state and federal judges to one another on questions of state and federal law, and the tension between consistency and correctness.

We conclude that when hitigation spans state and federal courts, informal coordination can advance judicial economy, efficiency, and fairness. This Article seeks to promote such coordination im a manner consistent with the interests of the judiciary, the hitigants, and the public.

\section{Related Multiforum Litigation}

Most related multiforum litigation results from mass torts: situations in which numerous imjuries and, therefore, numerous lawsuits result from the same event or set of circumstances. Because these claims are usually based on state law, many of thein are filed in state court, although those cases involving parties of wholly diverse citizenship may be filed in or removed to federal court. Even when the allegedly tortious conduct is goverued by a federal statute, cases often end up im both judicial systems because federal and state courts have concurrent jurisdiction over most federal law claims. ${ }^{8}$

8 See Claflin v. Houseman, 93 U.S. 130, 136-37 (1876). Although torts are the paradigm, they are not the only type of claim giving rise to multiforuin litigation. Various statutory violations or breach of warranty actions may also trigger litigation in multiple forums. 
Related multiforum litigation generates duplicative proceedings ${ }^{9}$ that produce great expense ${ }^{10}$ and delay, ${ }^{11}$ and thus frustrate plaintiff' recovery of compensation. ${ }^{12}$ Court dockets become even more crowded, thereby affecting all hitigants in the civil justice system. ${ }^{13}$ In addition, different courts can

9 For example, depositions of witnesses, pertaining to identical matters, are taken by multiple plaintiffs. See, e.g., In re Motion Picture Licensing Antitrust Litig., 468 F. Supp. 837, 841-42 (J.P.M.L. 1979) (consolidating cases in part "to prevent duplicative discovery"). Similarly, identical or similar motions are filed in countless courts, and the same issues are repeatedly adjudicated. See Richard D. Freer, Avoiding Duplicative Litigation: Rethinking Plaintiff Autonomy and the Court's Role in Defining the Litigative Unit, 50 U. Pitt. L. Rev. 809,811 (1989) ("Relitigation of identical issues wastes scarce judicial resources in both federal and state courts."); John C. McCoid, A Single Package for Multiparty Disputes, 28 Stan. L. Rev. 707, 707 (1976) ("[R]epeated examination of the issues raised by a single transaction is a waste."); David Rosenberg, Class Actions for Mass Torts: Donig Individual Justice by Colleetive Means, 62 Ind. L.J. 561, 563 (1987) (mass torts require "courts to reinvent the wheel for eacls claim").

10 Both litigants and the courts incur high expenses from mass torts. See Mark A. Peterson \& Molly Selvin, Institute for Civil Justice, Resolution of Mass Torts: Toward a Framework for Evaluation of Aggregative Procedures 8-9 (1988) ("The total annount of money involved in mass tort litigation can be staggering, even when public costs are ignored. . . . Mass tort litigation also imposes an enormous burden on the court systern ...."); Robert H. Sand, How Much is Enough? Observations in Light of the Agent Orange Settlement, 9 Harv. Envtl. L. Rev. 283, 297-98 (1985) (estimating that in the Agent Orange litigation a set of depositions pertaining to a single defense cost $\$ 13,440,000)$; Spencer Williams, Mass Tort Class Actions: Going, Going, Gone? 98 F.R.D. 323, 324 (1983) (predicting that mass tort cases could conceivably "bankrupt both the state and federal court systenn").

11 The expense and delay im mass tort hitigation result from the large numbers of documents and witnesses, the difficulty of coordinating the sclredules of nultiple parties and attorneys, and the complexity of issues, all of which occasion prolonged discovery and investigation, extensive motions, and lengthy trials. See Report of the Judicial Conference Ad Hoc Committee on Asbestos Litigation 10-14 (1991) (discussing causes of delays in and high costs of asbestos litization); Martin I. Kaminsky, Proposed Federal Discovery Rules for Complex Civil Litigation, 48 Fordliam L. Rev. 907,909 n.11 (1980). Asbestos cases, for example, average 30 months from filing to disposition, almost double the target set by the Civil Justice Reforn Act of 1990. See Report of the Judicial Conference Ad Hoc Committee on Asbestos Litigation, supra, at 10-11.

12 High transaction costs, such as attorneys' and witness' fees, greatly reduce the actual comipensation received by prevailing plaintiffs. See James S. Kakalik, Patricia A. Ebener, William L.F. Felstiner \& Michael G. Slranley, Institute for Civil Justice, Costs of Asbestos Litigation at viii, 40 (1983) (noting that the average asbestos plaintiff receives an amount equal to 37\% of total trial expenses); Roger H. Trangsrud, Jonider Alternatives in Mass Tort Litigation, 70 Coruell L. Rev. 779, 781 n.8 (1985); Jack B. Weinstein, The Role of the Court in Toxic Tort Litigation, 73 Geo. L.J. 1389, 1389 (1985) ("[T]lie cost of delivering compensation through the courts is too high when the cost of the transaction and the anount received by the person seeking conpensation are conpared.").

13 See Report of the Judicial Conference Ad Hoc Colnmittee on Asbestos Litigation, supra note 11, at 12 ("The parties in asbestos cases are not the only parties affected .... Districts with heavy asbestos caseloads necessarily experience increased delays in otler civil nuatters."); 
reach divergent decisions on nearly identical factual and legal issues, producing unfairness and uncertainty. ${ }^{14}$ Moreover, the sheer number of claims can render defendants insolvent and consequently prevent future plaintiffs from receiving any compensation. These phenomena, in turn, increase public dissatisfaction with the justice system and the legal profession. ${ }^{15}$

Such consequences have sparked a search for effective ineans of aggregating cases that arise from common causes. ${ }^{16}$ Federal courts are now able to aggregate or consohidate federal cases to soine extent. ${ }^{17}$ Because state courts coinprise fifty independent judiciaries, however, less can be done to aggre-

Rosenberg, supra note 9, at 564 (mass torts "consume[ ] vast quantities of public resources, raising the price of access for other ... types of tort claims").

14 See Peterson \& Selvin, supra note 10:

[O]utcomes will be inconsistent. Witl multiple trials some plaintiffs will receive nothing, whereas others will receive exceptionally large awards for essentially similar claims. Defendants and observers will have little guidance about future conduct because they receive inconsistent signals about the propriety of their actions. Differing state laws (e.g., statutes of limitations, availability of punitive dainages) contribute to this inconsistency.

Id. at 12 (footnote omitted); see also Jack B. Weinstein, Preliminary Refleetions on the Law's Reaction to Disasters, 11 Colum. J. Envtl. L. 1, 16 (1986) ("It is essential that there be a single, easily determined and authoritative substantive law applied to the litigation so that the parties know in advance what the law provides.").

15 See Dreis \& Krump Mfg. v. International Ass'n of Machinists Dist. No. 8, 802 F.2d 247, 255 (7th Cir. 1986) (noting "growing public dissatisfaction with the costs and delays of litigation"); Steplıen D. Sugarman, Taking Advantage of the Torts Crisis, 48 Ohio St. L.J. 329,337 (1987) (noting that some mass tort hitigation lias "helped to reinforce the stereotypical negative view of lawyers," and concluding that it is "potentially quite a bad thing for the public at large to loold both lawyers and the law in low esteem").

16 See Judith Resnik, From "Cases" to "Litigation," 54 Law \& Contemp. Probs., Summer 1991 , at 5,55 "The perceived utility of centralization is overwhelming the few voices that argne for the desirability of continuing to have multiple and overlapping cases and court systems.").

17 All related cases in a single jurisdiction may be assigned to the saine judge. Further, Rule 42(a) of the Federal Rules of Civil Procedure authorizes the consolidation of actions pending in one judicial district, and 28 U.S.C. $\$ 1404$ (a) empowers district courts to transier a case to any district in which it could liave been brought.

Most significantly, 28 U.S.C. $\$ 1407$ authorizes the Judicial Panel on Multidistrict Litigation ("JPML") to transfer related civil actions pending in different courts to any district for coordinated or consolidated pretrial proceedings. Under $\$ 1407$, transferee courts may oversee settleinent and summary judgment procedures. Further, pursuant to $\S 1404(a)$, transferee judges can retain many of the lawsuits for trial. See, e.g., In re Fine Paper Antitrust Litig., 685 F.2d 810, 818-20 (3d Cir. 1982), cert. denied, 459 U.S. 1156 (1983); see also George T. Conway III, Note, The Consolidation of Multistate Litigation in State Courts, 96 Yale L.J. $1099,1102 \mathrm{n} .23$ (1987) (noting that "[c]ourts have consistently held that a $\S 1407$ transferee court may transfer multidistrict litigation to itself for trial under 28 U.S.C. $\$ 1404(a) ")$. Thus, although the applicability of the statute is limited to pretrial proceedings, it lias led to the aggregated resolution of numerous claims. See Patricia D. Howard, A Guide to Multidistrict 
gate cases dispersed throughout the state systems. ${ }^{18}$ Moreover, only limited procedures are available for transfer of cases from state to federal court. ${ }^{19}$ Defendants may "remove" certain cases from state court to federal court, ${ }^{20}$ and federal courts can exercise "supplemental jurisdiction" over various

Litigation, 75 F.R.D. 577, 578 (1978) (noting "the great success of the transferee judges in terminating [actions] by settleinent, summary judgment, or other type of dismissal").

The potential of $\S 1407$ as a consolidation device is illustrated by the JPML's recent decision to consolidate over 26,000 asbestos cases in the District Court for the Eastern District of Pennsylvania. In re Asbestos Prods. Liab. Litig. (No. VI), 771 F. Supp. 415 (J.P.M.L. 1991). The transfer meclianisins are limited, lowever. As noted, $\S 1407$ is limited to pretrial proceedings. Section 1404(a) enables the transferee court to retain some consolidated cases for trial, but only those that conld have been brought there initially. Sec Elinor P. Schroeder, Relitigation of Common Issues: The Failure of Nonparty Preclusion and an Alternative Proposal, 67 Iowa L. Rev. 917, 917 n.2 (1982) (observing that "28 U.S.C. § 1404(a) (1976), allows a federal court to transfer an action to another federal court for the convenience of parties and witnesses' and 'in the interest of justice,' but the transferee court must be one in whicl venue and jurisdiction would liave been proper origimally.").

18 There is no interstate transfer and consolidation tool akin to 28 U.S.C. § 1407. Sonre commentators have proposed that states adopt sucli a device. Sce, e.g., Schroeder, supra note 17, at 965. The National Conference of Commissioners of Uniform State Laws recently recommended that all states enact a Uniform Transfer of Litigation Act-providing for interstate transfers of both pretrial actions and trials-initiated by the transferor court but requiring acceptance by the transferee court. Unif. Transfer of Litig. Act, 14 U.L.A. 78 (Supp. 1992); sec also American Law Inst., Complex Litigation Project (Tentative Draft No. 3, 1992) (addressing, in part, "the problem of transfer of litigation from one state to another").

There are valuable aggregation devices available within sonre states. Many states have rules similar to Fed. R. Civ. P. 42(a) authorizing consolidation of related actions. See, e.g., Cal. Civ. Proc. Code $\S \S 404 .-404.8$ (West 1973 \& Supp. 1992); Iowa R. Civ. P. 185; Kan. Stat. Ann. $\S$ 60-242 (1983); Miclı. Ct. R. 2.505; Minn. R. Civ. P. 42.01; Mo. R. Civ. P. 66.01(b); Wis. Stat. Ann. $\S 805.05(1)$ (West 1977 \& Supp. 1990). A few state courts have iniphicitly recognized an inherent judicial power to consohidate certain cases. See, e.g., Means v. Montana Power Co., 625 P.2d 32, 36 (Mont. 1981) (ruling that the trial court, "in exercising its managerial power" over the case, did not abuse its discretion in "providing for the apponitnient of a lead connsel" in consolidation of the case). See also Jack B. Weinstein \& Eileen B. Hershenov, The Effect of Equity on Mass Tort Law, 1991 U. Ill. L. Rev. 269 (suggesting that judges' equitable powers permit thein to take mcasures not directly authorized by formal rules).

19 Additionally, in "exceptional" circumstances a federal court inay stay its proceedings out of deference to pending state court proceedings. See Colorado River Water Conservation Dist. v. Umited States, 424 U.S. 800, 818 (1976) ("[T] he circumstances permitting the dismissal of a federal suit due to the presence of a concurrent state proceeding for reasons of wise judicial administration are considerably inore limited than the circumstances appropriate for abstention. The former circunistances, though exceptional, do nevertheless exist."); Schounber v. Jewel Cos., 614 F. Supp. 210, 218 (N.D. Ill. 1985) (staying federal proceedings where state court had undertaken complex administrative procedures to oversee the action).

20 The general removal statute, 28 U.S.C. § 1441 (1988 \& Supp. II 1990), enables defendants, subject to limitations, to reniove actions over which the federal courts have original diversity or federal question jurisdiction. 
claims or cases. ${ }^{21}$ These devices are, however, applicable only in limited circuunstances ${ }^{22}$ and their use cannot be imitiated by the court. ${ }^{23}$

The class action, either federal ${ }^{24}$ or state, ${ }^{25}$ is a potentially inore significant ineans of intersystem consolidation. If, however, ineinbers of the certified class are permitted to "opt out," only limited consolidation will be achieved. A mandatory class action (i.e., one where class ineinbers may not opt out), by contrast, brings all related claims into a single case. Yet, federal appellate courts have often rejected mandatory class actions in inass tort litigation, ${ }^{26}$ especially where certification interferes with cases in the state

21 Supplemental jurisdiction is an umbrella term embracing pendent claims, pendent parties, and ancillary jurisdiction, all of which involve a federal court entertaining a state claim over which it has no independent subject matter jurisdiction. 28 U.S.C. § 1367 (Supp. II 1990). When a plaintiff states both federal and state claims based on sufficiently similar facts, the federal court may exercise "pendent jurisdiction" over the state claim. In some circumstances, the court may exercise "pendent party jurisdiction" over a party in the absence of an independent basis for jurisdiction, if the claim against the party is sufficiently related to one made against a party over whose claim the court has federal question jurisdiction. "Ancillary jurisdiction" is a kind of pendent party jurisdiction arising from counterclaims, cross-claims, third-party claims, and intervenors' claims lacking an independent basis for federal jurisdiction but intimately connected to a case properly before the court.

22 Sec American Law Inst., Report: Preliminary Study of Complex Litigation 62 (1987) (noting that "[p]endent and ancillary jurisdiction may be helpful to a limited extent in preventing parallel hitigation in state and federal court, or in separate actions, of issues common to more than one claim between the same parties," but that "this pattern of dispersion is not a inajor component of the complex litigation problem"). Moreover, pendent party jurisdiction is not permitted when the federal court's jurisdiction is based on diversity, which is generally the case in mass torts. Id. at 61 . Interpleader is another procedural device that enables federal courts to lear consolidated state and federal claims, Fed. R. Civ. P. 22, but it too applies only in rare circumstances.

23 Removal is at the discretion of defendants. See infra notes $31-42$ and accompanying text (discussing proposals to broaden removal). Likewise, although federal courts liear pendent state claims, nothing prevents plaintiffs from brimging the claims in state court instead. An intervenor, as well as a party, inay invoke ancillary jurisdiction, but the court may not.

24 Fed. R. Civ. P. 23.

25 Most states have enacted statutes authorizing class actions. Sec Note, Multistate Plaintiff Class Actions: Jurisdiction and Certification, 92 Harv. L. Rev. 718, 718-19 \& nn.6-9 (1979).

26 See In re Fireboard Corp., 893 F.2d 706, 712 (5th Cir. 1990) (vacating class because of insufficient commonality); In re Federal Skywalk Cases, 680 F.2d 1175, 1180-83 (8th Cir.) (vaeating class certification order because its effect on state court actions violated the AntiInjunction Act), cert. denied, 459 U.S. 988 (1982); sec also Linda S. Mullenix, Beyond Consolidation: Postaggregative Procedure in Asbestos Mass Tort Litigation, $32 \mathrm{Wm}$. \& Mary L. Rev. 475, 482-83, 500-02 \& nn.125-27 (1991) (noting federal courts' resistance to certifying mass tort claims for class action, and citing relevant cases and literature). 
system. ${ }^{27}$ More importantly, mandatory class actions may be unavailable when the trial court lacks personal jurisdiction over some of the parties. ${ }^{28}$

Bankruptcy proceedings offer another means of imtersystem aggregation, because filing of a petition in bankruptcy stays all federal and state court actions involving the debtor, ${ }^{29}$ and permits centralization of claims against it. This opportunity only arises, however, when a defendant (or its creditor) files for bankruptcy-a relatively rare occurrence. Moreover, related multiforum hitigation often imvolves several defendants, so bankruptcy proceedings involving a single defendant will permit piecemeal hitigation to continue rather than lead to significant aggregation. ${ }^{30}$

The current means of achieving imtersystem aggregation and consolidation are clearly hinited. A number of legislative proposals for enlarging the power of courts to achieve intersystem aggregation and consolidation have been advanced. We now turn to a brief review of these proposals.

27 See, e.g., In re School Asbestos Litig., 789 F.2d 996, 1002 (3d Cir.) (vacating certification of a mandatory class in part because it implicated "serious questions of personal jurisdiction and intrusion into the autonomous operation of state judicial systems"), cert. denied, 479 U.S. 852, and cert. denied, 479 U.S. 915 (1986).

28 In Phillips Petroleum Co. v. Shutts, 472 U.S. 797 (1985), the Supreme Court upheld an opt-out class despite the fact that sone plaintiffs lacked the minimum contacts with the forum state usually required for personal jurisdiction. It reasoned that by not opting out, plaintiffs consented to jurisdiction. The Court stated that "due process requires at a minimum that an absent plaiutiff be provided with an opportunity to remove himself from the class." Id. at 812. On its face, this language seems to preclude nrandatory class actions. See Arthur R. Miller \& David Crump, Jurisdiction and Choice of Law in Multistate Class Actions After Phillips Petroleum Co. v. Shutts, 96 Yale L.J. 1, 39 (1986) (footnote omitted) ("[T] expressed in Shutts, that the right to opt out is a fundamental due process requirement seeins to contradict the mandatory class action that has developed under Federal Rule 23 and its state counterparts."). Alternatively, Shutts may be seen as prohibiting mandatory classes when any class members lack requisite contact with the forum state. See, e.g., Waldron v. Raymark Indus., 124 F.R.D. 235, 238 (N.D. Ga. 1989). Sone commentators claim that mandatory classes remain possible even then, if "equity and efficiency factors [are] so compelling as to overcome distant forum abuse concerns." Miller \& Crump, supra, at 53. In any case, Shutts severely limits inandatory class actions in both state and federal courts, with its impact apparently greatest in the state courts. See generally American Law Inst., supra note 22 , at $42,47-48,101,104,158-59$ (discussing the use of the class action as a nieehanisn for processing conplex litigation).

2911 U.S.C. $\S \S 105,362$ (1988 \& Supp. II 1990). In the federal systent, the district court has the power to withdraw and consider some actions referred to the bankruptcy court. 28 U.S.C. $\S 157(d)$ (1988).

30 See generally Margaret I. Lyle, Note, Mass Tort Claims and the Corporate Tortfeasor: Bankruptcy Reorganization and Legislative Compensation Versus the Common-Law Tort System, 61 Tex. L. Rev. 1297, 1314-36 (1983) (discussiug limitations and drawbacks of using bankruptcy proceedings to landle mass tort claims). 


\section{Proposed Legislative Solutions}

Under the status quo, closely related cases often proceed independently in state and federal courts. Several proposals seek to alter this state of affairs by encouraging or requiring suits that currently end up in state court to be brought in or reinoved to federal court. ${ }^{31}$

Soine proposals call for Congress, under its power to regulate interstate commerce, to establish a federal tort law, at least for inass torts. Congress could enact statutes defining federal torts, ${ }^{32}$ or it could authorize federal courts to develop a federal common law of torts. ${ }^{33}$ Both approaches would greatly increase federal court jurisdiction over such torts. Alternatively, Congress might expand federal jurisdiction to include certain torts while preserving the apphication of state substantive law. ${ }^{34}$ For example, the American Bar Association Commission on Mass Torts recommended that Congress grant the federal courts jurisdiction over hitigation in which 250 or nore clamis, each seeking more than $\$ 50,000$ in damages, arise from either a single accident or from the use of or exposure to a single substance or product. $^{35}$ In such cases, a federal judicial panel (created by the proposed statute) could declare the cases pending in state and federal court "mass tort litigation" subject to consolidation. The panel could then transfer soine or all of the cases to a single federal court. A similar proposal would give federal courts jurisdiction over mass torts in cases of minimal diversity (i.e., when any plaimtiff and any defendant are from different states, as opposed to the current requirennent of complete diversity). ${ }^{36}$ This would enable more plaimtiffs to file in federal court and more defendants to remove to federal court.

${ }^{31}$ Some commentators would also authorize "reverse removal," whereby the JPML or a similarly constituted body could transfer cases from the federal courts to the state courts. See American Law Inst., supra note 18, at 15; Conway, supra note 17, at 1107-08.

32 See, e.g., Alvin B. Rubin, Mass Torts and Litigation Disasters, 20 Ga. L. Rev. 429, 44345 (1986) (arguing for uniform federal substantive tort law).

33 See, e.g., Linda S. Mullenix, Class Resolution of the Mass-Tort Case: A Proposed Federal Procedure Act, 64 Tex. L. Rev. 1039, 1077-79 (1986) (arguing for the development of a federal coninion law of torts).

34 Such statutes would arguably be authorized by the doctrine of "protective jurisdiction," under which Congress may give federal courts jurisdiction in areas in which it could enact substantive laws. See Verlinden B.V. v. Central Bank of Nig., 461 U.S. 480, 491 n.17 (1983) (citing Note, The Theory of Protective Jurisdiction, 57 N.Y.U. L. Rev. 933 (1982)) (declining to address constitutionality of "protective jurisdiction").

35 American Bar Ass'n Comm'n on Mass Torts, Report to the House of Delegates (1989).

36 See Thomas D. Rowe, Jr. \& Kenneth D. Sibley, Beyond Diversity: Federal Multiparty, Multiforum Jurisdiction, 135 U. Pa. L. Rev. 7, 10-11 (1986); Report of the Federal Courts Study Committee 44-45 (1990). The Federal Courts Study Committee report, like several proposals discussed infra, also recommended broadening 28 U.S.C. $\S 1407$ (a) to pernit consolidation of trials as well as pretrial proceedings. Id. at 45 . 
Congress is currently considering a bill that would give federal courts original and reinoval jurisdiction in cases that ineet the following prerequisites: the cause of action arises froin a single accident or event; the parties are minimally diverse; at least twenty-five persons have been killed or injured in the accident at a discrete location; and each claimant alleges damages in excess of $\$ 50,000 .{ }^{37}$ Under the bill, if the Judicial Panel on Multidistrict Litigation ("JPML") transferred all the federal cases to a single court for consolidated pretrial proccedings, the transferee court could retain all the cases for trial as well. Because, however, the bill would apply ouly to "single accident[s]," and not to successive exposure to products or substances, its scope is fairly limited.

The American Law Institute ("ALI") is considering whether to advocate a far-reaching statutory scheine ${ }^{38}$ that would replaee the JPML with a "Coinplex Litigation Panel" ("CLP") with greater power to transfer and consolidate cases. The CLP would have the authority to transfer state as well as federal cases, to consolidate cases for trial as well as pretrial proceedings, and to transfer select issues as well as entire actions. The sclieine's primary ineans for facilitating intersystem aggregation involves elimination of inany existing limitations on case reinoval. Currently, ouly defendants may reinove cases, and the general reinoval statute apphes ouly where the requirements of federal question or diversity jurisdiction are inet. ${ }^{39}$ Moreover, current law penmits removal only to the district court and division within whicl sucli action is pending. ${ }^{40}$ Whereas the JPML itself lias no reinoval power, the ALI scheine would authorize the CLP to reinove cases witliout any of the currently existing limitations. The scheme provides that whenever a state case bears a transactional nexus to and shares a common question of law or fact witl an already-filed federal case, the CLP inay order its reinoval and consolidation witl the federal case. ${ }^{41}$ There are no diversity requirements, and either one of the parties ${ }^{42}$ or the presiding state court judge inay initiate removal.

37 The initial version of this legislation was introduced in 1989. The latest version, H.R. 2450, 102d Cong., 1st Sess. (1991), was introduced in May 1991 and passed by the House in November 1991. Its prospects in the Senate are uncertain.

38 American Law Inst., Complex Litigation Project (Tentative Draft No. 2, 1990).

3928 U.S.C. § 1441(b) (1988).

40 Id. $\$ 1441$ (a).

41 Under current law, consolidation of a state case with a federal case usually requires a two-step process: removal under 28 U.S.C. $\$ 1441$ followed by a JPML transfer under 28 U.S.C. $\$ 1407$. The ALI's proposed statute would enable the CLP to consolidate directly a state case with federal cases.

42 One inay wonder why plaintiffs would ever want to remove cases they brought in state court. The answer is that circumstances can arise that were not present when the case was 
Although scrutiny of these and other proposals ${ }^{43}$ is beyond the scope of this Article, ${ }^{44}$ it is important to recognize that none of these proposals, even if adopted, would be a panacea. Most of them would redirect large numbers of cases from the state courts into the already overburdened federal courts, without advancing the cause of aggregation unless all of the cases were brought into a single federal court. But if all of the cases ended up in one court, that court could be paralyzed by the litigation. ${ }^{45}$

These legislative proposals, then, all have serious shortcomings. Moreover, Congress has not shown great interest in these formal mechanisms and is not likely to enact any of them in the foreseeable future. But even within the existing system, the judiciary, togetler witl counsel, can take effective action to reduce costs, delays, and mefficiencies. When related claims are pending in state and federal courts, judges in the two systems can informally coordinate their proceedings. This has already happened in several cases, and an analysis of the results, undertaken in the following Part, is a critical first step for assessing the potential and the limitations of sucli arrangements.

filed. For example, a federal case might be filed to which the state case might fruitfully be joined.

43 In addition to the proposals discussed in the text, several other reforms have been suggested. The ALI project explored the possibility of an Interstate Complex Litigation Compact or, alternatively, an Interstate Complex Litigation Act, which would establish a regime for the aggregation of complex litigation among the consenting states and, in the case of a coinpact, the federal courts. See American Law Inst., supra note 38, at 131. Other possible approaches are to expand the doctrine of "issue preclusion," see Schroeder, supra note 17, or to set up an administrative claims system to compensate mass tort victims. See Francis E. McGovern, Resolving Mature Mass Tort Litigation, 69 B.U. L. Rev. 659, 693-94 (1989); Weinstein, supra note 14 , at 33-36.

44 It should be noted that the ALI proposal makes removal discretionary with the CLP, which is instructed to consider various federalism concerns, some of which will be discussed infra. It also bears mentioning that the ALI's proposed statute ensures the availability of suppleinental jurisdiction so that the transferee court can hear additional cases and claims. The proposed statute confers a transferee court with subject-matter jurisdiction over any claim that "arises from the same transaction, occurrence, or series of related transactions or occurrences" as the transferred claim, or "involves imdemnification arising from the same transaction" as the transferred claim. American Law Inst., supra note 38, § 5.03. Finally, it should be noted that the ALI also favors mcasures enabling transfer from federal to state courts and among state courts in different states. American Law Inst., supra note 18, at 15, $\S 4.01$.

45 Many of the proposals also encounter constitutional objections rooted in the jurisdictional limitations of Article III. See Linda S. Mullenix, Complex Litigation Reform and Article III Jurisdiction, 59 Fordham L. Rev. 169 (1990). 


\section{CASE Studies In INFormal INTERSystem CoORdination}

We have studied various cases in which state and federal judges coordinated proceedings before thein. ${ }^{46}$ In this Part, we draw on these case studies to analyze what kinds of coordination at what stages of litigation are most promising. To set the stage for that analysis, we offer a brief summary (in chronological order) of each instance of litigation we have studied in depth. ${ }^{47}$ Details of these and other cases will emerge in the following discussion of the nature of coordination that has been achieved at eacli stage of litigation.

\section{A. Illustrative Cases}

\section{Florida Everglades Air Crash}

On December 29, 1972, a jet aircraft flying froin New York to Miami crashed in the Florida Everglades, killing ninety-six passengers and imjuring many others. Lawsuits were filed in Florida state courts and in federal courts in Florida and New York. Eventually, the JPML transferred all the federal cases to the docket of Judge Peter T. Fay, then a District Judge for the Southern District of Florida, for coordinated pretrial proceedings. ${ }^{48}$ The Florida state cases were all assigned to Judge Harvie S. DuVal. Judges Fay and DuVal coordinated discovery extensively. They considered a joint statefederal trial on hability, but instead opted for the trial of two federal test cases, witl many of the state parties agreeing to be bound by the results. ${ }^{49}$ Ten days before trial, the parties settled on the hability issue. ${ }^{50}$ Disputes over damages were tried or settled by the judges within their own jurisdictions, without coordinatiou.

46 We intentionally selected different kinds of cases-products liability, securities law, accidents-to illustrate that the potential for state-federal coordination is not limited to a narrow range of cases. We did not undertake a comprelensive study of cases and no statistical conclusions should be drawn. But we believe the cases to be a generally representative sample. For an earlier example of coordination, see Paul D. Rheingold, The MER/29 Story-An Instance of Successful Mass Disaster Litigation, 56 Cal. L. Rev. 116 (1968).

47 The case summaries and the analysis that follow are based on interviews witl judges and attorneys as well as on examination of the paper record. Wherever there is no citation to a particular event, our source was the judge(s) involved in the case.

48 In re Air Crash Disaster at Fla. Everglades on Dec. 29, 1972, 368 F. Supp. 812 (J.P.M.L. 1973).

49 See In re Aircrasl Disaster at Fla. Everglades on Dec. 29, 1972, 549 F.2d 1006, 1009 (5th Cir. 1977).

so Id. at 1010. 


\section{Beverly Hills Supper Club Fire}

On May 28, 1977, a fire destroyed a nightclub in Kentucky, killing or injuring over 300 persons. Numerous lawsuits were filed in both the United States District Court for the Eastern District of Kentucky and in Kentucky state court. Because of a backlog in the Eastern District of Kentucky, Judge Carl B. Rubin of the Southern District of Ohio volunteered to hear the federal cases. He was designated to sit in the Eastern District of Kentucky and was assigned the cases. The state cases were before Judge John A. Diskin. The two judges coordinated all scheduling and pretrial activity. Judges Rubin and Diskin eventually divided the cases nito groups, sone to be tried in federal court, others in state court. Judge Rubin certified a federal class action involving the claims against inost defendants, ${ }^{51}$ and Judge Diskin certified a state class action nivolving the reniaining defendants. The cases proceeded to trials and verdicts in the two courts..$^{52}$

\section{Chicago Air Crash}

On May 25, 1979, a DC-10 aircraft departing O'Hare International Airport in Chicago en route to Los Angeles crashed shortly after takeoff, killing 273 people and injuring several others. Eventually nore than 150 wrongful death and personal injury suits were either filed in or removed to federal court, all based on diversity jurisdiction. The JPML transferred all the cases to Judges Edwin A. Robson and Hubert L. Will of the Northern District of Tllinois for consolidated pretrial proceedings. ${ }^{53}$ A nuniber of suits reniained in the state courts, including a cluster of seventy that were assigned to Judge Rafael H. Galceran in the Superior Court of Los Angeles County. The state and federal judges devised a joint discovery program, and exchanged infornation pertaining to settleinent efforts. The cases that did not settle were tried in their respective systeins, with the federal cases renianded to the district in which they had been originally filed or to which they had been reinoved. ${ }^{54}$

51 Coburn v. 4-R Corp., 77 F.R.D. 43 (E.D. Ky. 1977).

52 See In re Beverly Hills Fire Litig., 639 F. Supp. 915, 916 (E.D. Ky. 1986). Judge Rubin was succeeded by Judge Henry Rupert Wilhoit Jr. of the Eastern District of Kentucky when that court's docket permitted. Id. at 917.

53 In re Air Crash Disaster Near Chicago, Ill., on May 25, 1979, 476 F. Supp. 445 (J.P.M.L. 1979).

54 See Airline Disaster Litig. Report, 127 F.R.D. 405, 419 (N.D. Ill. 1988) (Liaison Counsel's final report and summary of proceedings). 


\section{Hyatt Skywalk Cases}

On June 17, 1981, two walkways in the Hyatt Regency Hotel in Kansas City, Missouri collapsed, killing more than 100 people and injuring over 200. Roughly twenty cases were filed in the United States District Court for the Western District of Missouri and over 100 in Missouri state court. The state cases were assigned to Judge Timothy D. O'Leary and the federal cases to Judge Scott O. Wright. ${ }^{55}$ The two judges coordinated discovery and discussed, but eventually abandoned, the idea of a joint state-federal trial. Judge Wright certified a inandatory federal class action. ${ }^{56}$ His order was vacated by the Eighth Circuit, but he later certified an opt-out class. ${ }^{57}$ Separate trials were scheduled in state and federal courts. Eventually, separate class-wide settleinents of both the state and federal cases were reached. ${ }^{58}$

\section{Ohio Asbestos Litigation}

During the early 1980s, asbestos claims were beginning to crowd a number of federal and state court dockets. Two judges in Ohio, Thoinas D. Lambros of the United States District Court for the Northern District of Ohio and James J. McMonagle of the Cuyahoga County Court of Common Plcas, determined that coordinating their asbestos cases would reduce cost and delay. In June 1983, all eighty asbestos cases in the Northern District were transferred to Judge Lambros' docket; ${ }^{59}$ approximately fifty cases were pending before Judge McMonagle at that time. The two judges decided to coordinate every stage of hitigation, with the state court tracking the federal court's forinal case nanagement plan. ${ }^{60}$ Judge McMonagle grouped and inoved his cases to correspond to the treatinent of the federal cases in order

55 In re Skywalk Cases, No. CV81-15244 MCF (Mo. Cir. Ct. Aug. 6, 1981) (order for preliminary consolidation of pre-trial discovery); In re Federal Skywalk Cases, No. 81-0593CV-W-3 (W.D. Mo. Sept. 2, 1981) (memorandum and order).

56 In re Federal Skywalk Cases, 93 F.R.D. 415 (W.D. Mo.), vacated, 680 F.2d 1175 (8tli Cir.), cert. denied, 459 U.S. 988 (1982).

57 In re Fed. Skywalk Cases, 95 F.R.D. 483 (W.D. Mo. 1982) (certifying an opt-out class).

58 See In re Federal Skywalk Cases, 97 F.R.D. 380 (W.D. Mo. 1983). The Skywalk litigation illustrates the potential for serious conflict and prejudice if proceedings go forward independently in state and federal court without coordination. See Scott O. Wright \& Joseplh A. Colussi, The Successful Use of the Class Action Device in the Managennent of the Skywalks Mass Tort Litigation, 52 UMKC L. Rev. 141 (1984) (stressing the importance of the mandatory class action). 67).

59 In re Ohio Asbestos Litig., No. 83-OAL (N.D. Ohio June 1, 1983) (General Order No.

60 See Ohio Asbestos Litigation: Case Management Plan and Case Evaluation and Apportioument Process, In re Ohio Asbestos Litig., No. 83-OAL (N.D. Ohio Dec. 16, 1983) (Order No. ๑). For a description of the plan, see Francis E. McGovern, Toward a Functional Approach for Managing Coinplex Litigation, 53 U. Chi. L. Rev. 440, 480-91 (1986). 
to facilitate simultaneous settlement. The two judges participated in joint settlement sessions in botli courts, and held joint sclieduling sessions and pretrial learings. They also coordinated discovery efforts. Coordination proceeded until Judge McMonagle's retirement in August 1990, and continued thereafter witlı some of the judges who took over his asbestos caseload.

\section{MGM Grand Hotel Fire}

On November 21, 1980, a fire in a Las Vegas liotel/casmo killed eiglityfour people and imjured over 1000 . Cases were filed in federal courts around the country, and in California and Nevada state courts. In May 1981, the JPML transferred all federal cases to the Umited States District Court for the District of Nevada for consolidated pretrial proceedings. Judge Louis C. Bechtle, of the Eastern District of Peunsylvania, volunteered to sit in Nevada and was assigued the cases. All of the cases in Nevada state courts had been consolidated before Judge J. Charles Thompson. The two judges engaged in extensive coordination of discovery proceedings. Their coordination extended to the settlement process as well, witl an eye toward a "global settlement," which they eventually achieved. ${ }^{61}$

\section{Technical Equities Fraud}

In 1986, Technical Equities Corporation, a San Jose real estate and investinent firm, went bankrupt, leaving 1200 investors with losses of over $\$ 150$ million on investments in stocks, partnership interests, and short-tern notes. Several hundred lawsuits were filed alleging fraud by the corporation's officers and directors. Additional suits were filed aganist accounting firms, banks, and insurance companies for aiding and abetting the alleged fraudulent conduct. Most of the cases were brought in California state court and eventually consolidated before Judge Conrad Rushnig. A handful of cases were filed in federal court, and assigued to Judge Willian A. Ingram of the Northern District of California. ${ }^{62}$

Judge Rushing appointed a settlement master for the state cases. The master enlisted the cooperation of Judge Ingram and Bankruptcy Judge Lloyd King (along witlı Judge Rushnig) in an effort to achieve a global settlement. Judge Rushing also appointed a state discovery master. Later, Judge Ingram appointed the sanie special discovery master for the federal cases. As a result, the two courts coordinated discovery. Two groups of state cases, using test-group plaimtiffs and applying the findings to similarly

61 In re MGM Grand Hotel Fire Litig., 570 F. Supp. 913, 917 (D. Nev. 1983).

62 See In re Technical Equities Fed. Sec. Litig., [1988-1989 Transfer Binder] Fed. Sec. L. Rep. (CCH) ๆ 94,093 (N.D. Cal. 1988). 
situated plaintiffs, have been tried-one in 1988, the other in 1990. A settleinent of the federal cases was reached in July $1991 .^{63}$

\section{L'Ambiance Plaza Collapse}

On April 23, 1987, L'Ambiance Plaza, a high-rise building under construction in Bridgeport, Connecticut, collapsed, killing twenty-eight people and injuring sixteen. Five cases were filed in federal court and assigned to Judge Warren W. Eginton, and others were filed in state court. Judge Eginton approached Federal Judge Robert C. Zampano, an alternative dispute resolution (ADR) specialist, about the possibility of using ADR. Believing that any settlement would have to include both the state and the federal cases, Judge Zampano formulated a plan for coordinated settleinent of all cases. The state cases were assigned for discovery to Judge James $T$. Healey and for settleinent to Judge Frank S. Meadow. Judges Zampano and Meadow put in place a mediation procedure for both the state and federal cases, while Judges Eginton and Healey coordinated discovery and held joint hearings. Eventually a global settlenent was achieved. ${ }^{64}$

\section{Brooklyn Navy Yard Asbestos Litigation}

After New York enacted two statutory changes in $1986,{ }^{65}$ its state and federal courts were inundated with asbestos-related lawsuits. By February 1988, over 5000 asbestos cases were pending in state and federal courts, many of them identical suits involving the same parties. ${ }^{66}$ The federal cases filed in the Eastern and Southern Districts of New York were all consohdated before Judge Charles P. Sifton of the Eastern District of New York. The cases filed in the state courts in the five counties of the City of New York were eventually consolidated before Justice Helen E. Freedman. By

${ }^{63}$ For the history of this litigation, see Howard Mintz, Judge OKs Settlement in Technical Equities Case, The Recorder, July 31, 1991, at 6; see also Industrial Indem. Co. v. Superior Court, 262 Cal. Rptr. 544 (1989) (giving brief history of case to date).

64 See In re L'Ambiance Plaza Litig., No. B-87-290(WWE) (D. Conn. \& Conn. Super. Ct. Dec. 1, 1988) (Special Settlement Proceedings).

65 Prior to 1986, causes of action accrued at the time of exposure to a harmful substance, but discovery of the injury often did not occur until long after the three-year statute of limitations had expired. The Toxic Tort Revival Statute substituted the date of discovery of an injury as the date on which the statute of limitations began to run for cases in which discovery occurred after July 1, 1986. The statute also created a one-year window, from July 30, 1986, to July 30,1987 , in which individuals could file previously time-barred claims for harms caused by five substances including asbestos. Act of July 30, 1986, ch. 682, 1986 N.Y. Session Laws 1565 (McKinney 1986).

66 Some plaintiffs bring identical actions in botl systems either to hedge their bets (because one of the suits could be dismissed for a jurisdictional or procedural defect) or to gauge the early progress of the cases in the two systems and then pursue the inore promising one. 
that time Judge Sifton had a management plan in place. Justice Freedman issued a inanagement plan for the state cases inodeled on the federal plan. ${ }^{67}$ The two judges made sure that they and the hitigants were kept abreast of related actions pending in each other's court system. They also coordimated their motion rulings, with each court sending a copy of its memoranda and orders to the other court, which would often follow the outcoine and reasoning when ruling on similar motions.

As the cases were proceeding to trial in the separate systems, Federal Judge Jack B. Weinstein suggested a consolidated state and federal court trial, presided over by Justice Freedınan and himself, involving all cases that arose from exposure to asbestos at the Brooklyn Navy Yard. In January 1990, the Brooklyn Navy Yard cases on Judge Sifton's docket, and those of other federal judges, were transferred to Judge Weinstein. ${ }^{68}$ Judge Weinstein and Justice Freedman coordinated all pretrial matters, ${ }^{69}$ includimg settleinent negotiations. They considered holding a joint state-federal trial, but eventually decided to try the cases separately, ${ }^{70}$ in part because most of the cases had already settled.

\section{The Exxon-Valdez Oil Spill}

On Marcli 24, 1989, the tanker Exxon-Valdez ran aground and ruptured on Bhigh Reef (approximately twenty-five miles froin the southern end of the Trans-Alaska Pipeline), releasing over eleven million gallons of crnde oil into the waters of Prince William Sound. During the ensuing montlss, the oil spread widely, contaminating waters, killing fisl and other animals, and affecting the livelihood of inany people. The spill led to assorted criminal and civil actions brought by the federal government, the State of Alaska, and the Native Alaskan Villages. In addition, private citizens filed hundreds of suits in both state and federal courts. The private claims were based on common law and on the Trans-Alaska Pipeline Authorization Act and parallel state legislation. The inajority of the federal actions were consolidated before Judge H. Russel Holland of the Uinted States District Court for the

67 See infra note 164 and accompanying text.

68 This process was facilitated by a January 23, 1990 order of Second Circuit Chief Judge James L. Oakes, temporarily designating Jack B. Weinstem to sit in the Southern District. See In re Eastern and S. Dists. Asbestos Litig., 772 F. Supp. 1380, 1385 (E. \& S.D.N.Y. 1991) (noting the designation of Judge Weinstein).

69 See In re Joint E. and S. Dists. Asbestos Litig., 129 F.R.D. 434 (E. \& S.D.N.Y. \& N.Y. Sup. Ct. 1990) (appoimtment of Special Master/Referee); In re Joint E. \& S. Dists. Asbestos Litig., 737 F. Supp. 735 (E. \& S.D.N.Y. \& N.Y. Sup. Ct. 1990) (denying motion to disqualify special master); In re New York City Asbestos Litig., 123 B.R. 7 (E. \& S.D.N.Y. \& N.Y. Sup. Ct. 1990).

70 See In re New York City Asbestos Litig., No. 40,000 (E. \& S.D.N.Y. \& N.Y. Sup. Ct. Sept. 12, 1990) (order that state and federal cases proceed separately). 
District of Alaska. The state actions were consolidated before Judge Brian Shortell.

Judges Shortell and Holland have engaged in extensive coordination of all pretrial matters, sometimes conducting joint hearings, and are currently developing a schedule to coordinate the state and federal cases in the trial phase.

\section{Sioux City Air Crash}

On July 19, 1989, a United Airlines flight from Denver to Chicago crashed at Sioux City, Iowa, killing 112 people. Cases were filed in state and federal courts around the country. Many were filed in Illinois state courts, and these were assigned to Judge Donald P. O'Connell. The JPML transferred all federal cases to Judge Suzanne B. Conlon of the Northern District of Illinois for consolidated pretrial proceedings. That court was chosen, in part, to "facilitate coordination among the federal and Illinois state court actions."71 The two courts coordinated discovery, kept one another updated on all activity in their respective courts, and aimed for consistent rulings. The cases eventually settled or were remanded to the districts in which they were originally filed.

A number of factors motivated the judges in these cases to coordinate their proceedings. ${ }^{72}$ Soine sought to prevent the "great duplication of effort and money" that would result "if both court systems were going to conduct discovery and hold hearings and ... settlement negotiations." ${ }^{\text {"73 }}$ Other judges worried that if the cases proceeded separately, scheduhing conflicts or other tensions between the court systems would inpede their progress. ${ }^{74}$ Still others were motivated by a desire for consistency in the state and fed-

71 In re Air Crash Disaster at Sioux City, Iowa, on July 19, 1989, 128 F.R.D. 131, 133 (J.P.M.L. 1989).

72 For some, the advantages of coordination were self-evident. Judge McMonagle recalls that it was "common sense to work together in the spirit of some type of cooperation." Interview with James J. McMonagle, Former Judge, Cuyahoga County Court of Common Pleas, Cleveland, Ohio (June 28, 1991) (on file with the Federal Judicial Center, Washington, D.C.). For Judge Rubin, deciding to manage the Beverly Hills litigation jointly with Judge Diskin was "like two plus two," because there was no other conceivable way to proceed. Interview with Carl B. Rubin, United States District Court Judge, Southern District of Ohio (July 5, 1991) (on file with the Federal Judicial Center, Washington, D.C.).

73 Interview with J. Charles Thompson, Judge, Eighth District Court of the State of Nevada in and for the County of Clark (July 17, 1991) (on file with the Federal Judicial Center, Washimgton, D.C.).

74 Knowing what the other judge is doing helps a court avoid interfering with the other's arrangements. Judge Holland says that he and Judge Shortell "are each endeavoring to be certain that we do not needlessly do anything that is going to get in the way of someone in the other court." Interview with H. Russel Holland, Chief Judge, United States District Court for 
eral treatinent of the cases in order to ensure comparable outcoines for similarly situated parties. ${ }^{75}$ Finally, a few judges believed that coordination would help them take charge of their cases. ${ }^{76}$ Mass hitigation can present an awesoine managerial task, and when judges work together they can jointly develop strategies to manage the hitigation and can reinforce each other's strategies. ${ }^{77}$

The discussion that follows confirms tliese views; coordinating state and federal cases accomplished important objectives. What follows is a description of how coordination was impleinented and how it fared at each stage.

\section{B. Discovery}

Discovery creates the greatest need and presents the greatest opportunity for coordination. Virtually all judges and attorneys who have participated im cases involving intersystem coordination agree that duplicative discoveryserving the same interrogatories on the same parties, taking depositions on the same inatters of the same witnesses, and producing the same documents and physical evidence in two courts rather than a common depository-is enormously wasteful. ${ }^{78}$ Thus, judges who want to streamline the litigation process frequently agrec that they will "first and foremost"79 coordinate discovery proceedings, and most attorneys are eager to assist. Intersystem coordination of discovery can be achieved in various ways. Though treated separately below, the different metlods of coordination are by no means mutually exclusive.

the District of Alaska, in Naples, Fla. (May 14, 1991) (on file with the Federal Judicial Center, Washington, D.C.).

75 Interview with Helen E. Freedman, Justice, New York Supreme Court, First Judicial District, in New York, N.Y. (July 11, 1991) (on file with the Federal Judicial Center, Washington, D.C.). Coordination reduces the opportunity for parties to play "one [court] against the other because the two judges, state and federal, [are] combined." Interview with Thomas D. Lambros, Chief Judge, Umited States District Court for the Northern District of Ohio, in Naples, Fla. (May 14, 1991) (on file with the Federal Judicial Center, Washington, D.C.). Judge Weinstein describes coordination as preventing parties from "put[ting] a wedge between" the two court systems and causing "whipsaws between the state and federal judges." Interview with Jack B. Weinstein, Judge, United States District Court for the Eastern District of New York, in New York, N.Y. (May 16, 1991) (on file with the Federal Judicial Center, Washington, D.C.).

76 See, e.g., Interview with Judge Carl. B. Rubin, supra note 72.

77 As one judge put it, "anytime a judge is at all hesitant, the lawyers will kill him." Id.

78 Even defendants who inay have incentives to prolong the hitigation process often agree that discovery is not the appropriate vehicle. Because discovery in mass litigation is complex, with numerous plaintiffs requesting similar documents and information, it is in defendants' interest to strive for efficiency and avoid undue burdens.

79 Interview with Chief Judge H. Russel Holland, supra note 74. 


\section{Joint Scheduling}

The most basic form of coordmation, which took place in the early stages of many of the cases we studied, imvolves scheduling discovery to proceed in tandem. This enables lawyers to prepare simultaneously for discovery im both courts, and gives judges an opportunity to exchange information and discuss discovery matters. Joint scheduling may also extend to other kinds of coordination, such as sharing resources, mcluding special masters and document depositories. Such an arrangement also enhances the chances of a global settlement, ${ }^{80}$ because all the parties are at the same stage of discovery and privy to the same information, and thus are more likely to make similar assessments about their prospects.

In the Exxon-Valdez litigation, the state and federal judges togetlier met with all the attorneys involved in the civil cases to discuss the organization of the hitigation and the potential for state-federal coordination. Following the initial conference, the judges entered identical orders $\mathrm{m}$ which they noted that sclieduling and planning for the state and federal cases "slrould, to the maximum degree feasible, proceed in tandem." ${ }^{81}$ Similarly, in the Sioux City air crash cases, Judge Coulon developed a discovery schedule that was later adopted by the state court.

Joint sclieduhing is not a one-time oceurrence. Because the progress of litigation cannot be fully anticipated at the outset, ongoing attention and scheduling adjustments will generally be necessary.

\section{Joint Discovery Plan}

In some imstances joint state-federal discovery plans have been developed. This gives a common structure to the discovery process and paves the way for extensive coordmation. The courts can either craft a discovery plan themselves or, as in the Exxon-Valdez litigation, ${ }^{82}$ direct counsel to do so. In the Ohio asbestos litigation, Judge Lambros appoimted two special masters to develop a management plan for the federal cases. This plan provided for truncated discovery to gather information necessary for individual case evaluation and settlement negotiations. Although the state court did not formally adopt this plan, Judge McMonagle issued an order announcing the state court's commitment to cooperate fully with it. In a jointly issued fed-

80 See infra text accompanying notes 105-35.

81 See In re the Exxon Valdez, No. A89-095 Civil (D. Alaska Aug. 25, 1989) (Pre-Trial Order No. 4).

82 In that case, the state and federal judges asked the attorneys to formulate a discovery plan that was subsequently adopted by both courts. It called for joint depositions and the joint appointment of a special discovery master. See In re the Exxon Valdez, No. A89-095 Civil (D. Alaska Feb. 9, 1990) (Discovery Order No. 2); Exxon Valdez Oil Spill Litigation, No. 3AN89-2533 Civil (Alaska Super. Ct. Feb. 9, 1990) (Pre-Trial Order No. 13). 
eral-state memorandum of accord, Judges Lambros and McMonagle expressed their "desire that there be a coordinated and uniform treatment of the asbestos cases pending before [their] two courts, and that the approach developed by the Special Masters will aid in the resolution of cases on both dockets." 83

Even without adopting a full-fledged common plan, state and federal courts can issue orders establishing a degree of coordination during discovery. In the Florida Everglades litigation, the courts created a master list of all litigants mvolved im the state and federal cases, and developed a procedure to allow each party to participate in all discovery proceedings. ${ }^{84}$ Similarly, in the Brooklyn Navy Yard hitigation, the state and federal judges required litigants to inform each other of related actions pending in the other system, and provided for joint listing of and attendance at depositions.

\section{Common Discovery Master}

State and federal courts may make a joint appointment of a special master to supervise discovery im both state and federal cases. A common discovery master can help reduce duplicative discovery and ensure consistency by establishing common standards and procedures for the state and federal cases. This, in turn, reduces the imcentive for forum shopping and provides guidance on how future matters will be handled. ${ }^{85}$

Federal magistrates have often been chosen to serve im this capacity. ${ }^{86}$ In the Brooklyn Navy Yard litigation, Judge Weinstein and Justice Freedman desiguated a federal magistrate to settle discovery disputes for both courts. In the MGM Hotel litigation, prior to state-federal coordination, the federal judge appointed a federal magistrate to hear discovery matters. ${ }^{87}$ Later, when the state and federal cases were coordinated, the federal magistrate ruled on both state and federal matters.

Separate appointments of a common discovery master can achieve many of the benefits of a joint appointment. In the Techrical Equities hitigation, the state and federal judges, at separate times, appointed the same individual

${ }^{83}$ In re Ohio Asbestos Litig. (N.D. Ohio \& Ct. C.P. Cuyahoga County July 14, 1983) (Federal-State Memorandum of Accord on Asbestos Litigation).

84 In re Aircrash Disaster at Fla. Everglades on Dec. 29, 1972, 360 F. Supp. 1394, 1396-97 (J.P.M.L. 1973).

85 As one master explains, discovery masters develop a "track rccord," and "word gets around" and "lawyers act accordingly." Interview with James McMamis, Esq. (Sept. 12, 1991) (on file with the Federal Judicial Center, Washington, D.C.). Mr. McManis served as special master for both the state and federal court to facilitate discovery in the Technical Equities litigation.

${ }^{86}$ See Fed. R. Civ. P. 72 (authorizing magistrates to handle pretrial matters).

87 In re MGM Grand Hotel Fire Litig., 570 F. Supp. 913, 917 (D. Nev. 1983) (citing Pretrial Order No. 6). 
to oversee discovery matters in their respective courts. The master developed common procedures for both state and federal discovery, and also provided other valuable services. He had contact with both the state and federal judges and acted as a haison between them. In addition, because the inaster was aware of the discovery undertaken in both the state and federal hitigation, if a witness had already been deposed, the master would so inform any other party seeking to depose that witness. In general, he encouraged all counsel to read and familiarize themselves with the record in an effort to avoid plowing the same ground. ${ }^{88}$ The discovery master helped coordinate the proceedings of the state and federal courts even when more extensive coordination between the judges was not feasible.

The appointment of a joint special master is often difficult. Rule 53(b) of the Federal Rules of Civil Procedure states that appointment of a master "shali be the exception and not the rule" and specifies the ouly instances in which such an appointment is justified: 1) in a jury trial if "the issues are complicated"; 2) in a bench trial "upon a showing that some exceptional condition requires it"; or 3) in any cases where the parties consent to having a federal magistrate serve as master. ${ }^{89}$ Despite the textual limitations, use of special inasters "has proliferated in a wide variety of sitnations, ouly a few of which are expressly contemplated by the Rule."90 Furthermore, differences among federal courts' and state courts' authority to appoint masters may frustrate a joint state-federal appointment. ${ }^{91}$ In the Ohio asbestos hitigation, for example, no joint appointment was made because State Judge McMonagle did not think he had the authority to appoint a special master.

\section{Joint Use of Discovery Materials}

Regardless of whether the cases are proceeding in accordance with coordinated schedules, under a common plan, or using a common special master, the courts can ensure that material discovered in one case can be used in compamion cases. Courts may simply accept discovery initially (or concurrently) developed in other cases. Several courts have issued orders providing that discovery taken in another court's case could be used in the proceedings of the court issuing the order. ${ }^{92}$ These orders can apply to all forms of discovery or be himited in scope. In the Chicago air crash hitigation, for exam-

88 Interview with Norman Blears, Esq., Heller, Ehrman, White \& McAuliff, Palo Alto, Cal. (Sept. 12, 1991) (on file with the Federal Judicial Center, Washington, D.C.).

89 Fed. R. Civ. P. 53(b).

90 Weinstein \& Hershenov, supra note 18, at 301.

91 For example, in Arizona a master may be appointed for bench trials only. Ariz. R. Civ. P. 53(a). But see infra text accompanying notes 127-32.

92 See, e.g., In re New York City Asbestos Litig., No. 40000 (N.Y. Sup. Ct. March 25, 1988) (Case Management Order No. 1). 
ple, the state and federal courts agreed to accept discovery material developed in the other court pertaining to hability. ${ }^{93}$

Judges generally have been willing to allow depositions taken in a case in one court system to be used im related cases pending in the other. In some instances, such as the Beverly Hills Supper Club hitigation, the courts suggested, but did not imsist on, joimt depositions. Other courts have prohibited hitigants from duplicating depositions in companion cases. In the Brooklyn Navy Yard litigation, the judges experimented with each of these methods. State defendants were originally given the option of attending depositions conducted by federal defendants or deposing the same parties at another time. Justice Freedman later ordered all state defendants to appear for federal depositions in all cases filed in both courts, however, statimg that failure of counsel to participate in those depositions would be deemed a waiver of discovery.

Attorneys tend to approve of joint depositions and sometimes agree to them even when not required. In the Exxon-Valdez litigation, the attorneys' discovery plan specifically provided for common depositions. In the Hyatt Skywalk hitigation, a State-Federal Liaison Committee, composed of lawyers, voluntarily coordinated the taking of depositions for both the state and federal cases. ${ }^{94}$ Similarly, in the Beverly Hills Supper Club hitigation, the attorneys agreed that all depositions could be used in both the federal and state actions, and conducted some joint state-federal depositions. ${ }^{95}$

State and federal courts have also coordimated the use of interrogatories. In the Brooklyn Navy Yard litigation, for exaniple, the state court's case management plan provided that interrogatories filed im the federal court would apply to all cases pending in the state court. In the Hyatt Skywalk cases, the State-Federal Liaison Committee was given the task of drafting interrogatories applicable to cases pending in both the state and federal systems.

In some instances, state and federal courts have created common document and physical evidence retention plans. These plans generally provide for joint depositories accessible to all federal and state counsel and parties. These depositories can be supervised by botli the state and federal courts or can be maintained by one court with the other making use of the facilities.

93 See, e.g., Airline Disaster Litigation Report-Uniform Damage Rules Needed, 127 F.R.D. 405 (1988) (Liaison Counsel's final report and summary of proceedings in In re Air Crash Disaster Near Chicago, Ill, on May 25, 1979).

94 Interview with Timothy D. O'Leary, Judge, Circuit Court of Jackson County, Mo., (Sept. 9, 1991) (on file with the Federal Judicial Center, Washington, D.C.). See infra text accompanying notes 223-25.

95 Interview with Judge Carl B. Rubin, supra note 72. 


\section{Joint Discovery Hearings}

Some judges have recognized that although not all aspects of the related cases could be aggregated in one court, important inatters could be heard in a single proceeding. In the Beverly Hills Supper Club hitigation, for example, Judges Rubin and Diskin frequently sat "together on the bench"96 and heard discovery motions. They sat together every two or three months to dispose of all disputes. In the L'Ambiance Plaza hitigation, Judge Zampano recognized the importance of having a state counterpart for Judge Eginton, who was handling discovery for the federal cases. He communicated this view to the Chief Court Administrator for the State of Connecticut, and subsequently all state cases were assigned for discovery purposes to Superior Court Judge James T. Healey. Alternating between the state and federal courts, Judges Healey and Eginton inet with attorneys and conducted joint discovery hearings. More recently, in the Brooklyn Navy Yard hitigation, Judge Weinstein and Justice Freedinan, along with the federal inagistrate appointed to handle discovery disputes, sat together on numerous occasions.

These discovery hearings are discussed below in connection with joint pretrial hearings generally. Here, it is sufficient to note that because the discovery issues that arise in state and federal courts are generally similar, joint hearings are possible and can help dispose of matters expeditiously.

\section{Resolving Differences}

Although state and federal procedural and evidentiary rules soinetimes differ, these differences have generally not impeded coordination of discovery. Judges who coordinate proceedings find that state and federal discovery rules are usually coinpatible. ${ }^{97}$ In the Exxon-Valdez hitigation, for example, Judge Holland found it easy to have one special master handle discovery for both courts because the federal and the Alaska state rules are essentially the same. $^{98}$ In the L'Ambiance Plaza litigation, Judges Eginton and Healey found that carefully wording texts and exchanging drafts enabled them to formulate orders that satisfied both the state and federal rules. ${ }^{99}$

At times, judges liave avoided conflict by mamtaining an "open" discovery policy. As one judge involved in the Florida Everglades litigation recalls, "what went on in discovery wasn't going to have a thing to do with

96 Id.

97 See Daniel J. Meador, Are We Heading for a Merger of Federal and State Courts?, 17 Judges' J. 9, 47 (1978) ('Some 40 states have adopted rules of civil procedure which are virtually identical to the Federal Rules of Civil Procedure. Greater uniformity in the law of evidence may likewise follow the adoption of the Federal Rules of Evidence.").

98 Interview with Chief Judge H. Russel Holland, supra note 74.

99 They issued separate orders, but with the same text. 
whether [material] was admissible as evidence [in court]."100 Differences in procedures and rules were thus glossed over early in the hitigation and differences in interpretation or application of rules were rare. One judge involved in a cooperative scheine reinarked that inost decisions were so "obvious" that anyone would have decided thein the same way. ${ }^{101}$

When conflicts did arise, judges employed a variety of inechamisms to resolve thein. Where federal procedures differed significantly froin state procedures, some courts agreed to apply federal law to all discovery matters, presumably because the federal rules tend to be inore hiberal. ${ }^{102}$

A pohicy of deference often forestalls possible conflict. In the Sioux City hitigation, a dispute arose over whether certain documents sought during discovery were protected by the attorney-chent privilege or work product rule. The issue was raised first in the federal court and decided by a federal magistrate. Perceiving the need for consistency, State Judge O'Connell issued an order similar to the one issued by the federal court. Similarly, during the early stages of the Brooklyn Navy Yard hitigation, State Supreine Court Justice Freedman often deferred to the discovery rulings issued by the federal court, which was further along in the hitigation. (She did, however, remain involved in the decisionmaking process-the state and federal judges maintained contact and conferred about these inatters prior to several federal court rulings.)

In soine cases, especially the earher ones, the federal court took the lead in handling all discovery matters. In the MGM Hotel Fire hitigation, all discovery was supervised by Federal Judge Bechtle. State Judge Thoinpson issued an order providing that discovery pertaining to hability issues in the state cases be "inade in, conducted through, and governed by" the federal hitigation. ${ }^{103} \mathrm{He}$ ruled that all depositions and documents generated froin state cases had to be filed in the federal court rather than the state court. All motions were heard by the federal judge. A similar situation developed in the Florida Everglades litigation. Because the federal cases were proceeding at a faster pace than those in the state court, Federal Judge Fay heard all motions regarding discovery matters; the state court autornatically ratified

100 Interview with Peter T. Fay, Judge, United States Court of Appeals for the Fifth Circuit, in Miami, Fla. (May 13, 1991) (on file with the Federal Judicial Center, Washington, D.C.).

101 Interview with Justice Helen E. Freedinan, supra note 75.

102 Judge Weinstein and Justice Freedman decided that discovery for the Brooklyn Navy Yard cases would proceed under federal law and would be used in both the state and federal cases. Interview with Judge Jack B. Weinstein, supra note 75 . In the Beverly Hills Supper Club hitigation, conflicts arising during joint depositions were resolved by a federal inagistrate applying federal law.

${ }^{103}$ In re MGM Grand Hotel Fire, No. A201150 (Nev. Dist. Ct. for Clark County Sept. 26, 1981) (First Pre-Trial Order). 
his orders unless counsel objected. As discussed below, federal courts often have institutional advantages, greater resources, and more flexible tools for aggregating their own cases that may make it advisable for them to take the lead im discovery.

Conflicts can also be avoided through specialization rather than deference. Judge O'Leary recounts that during the Hyatt Skywalk hitigation, the federal judge would rule on matters raised by the federal case attorneys, and the state judge would rule on matters raised by state case attorneys. The judges and attorueys in that hitigation also developed a "golden rule": before attorneys could raise a discovery matter with the judges, the attorneys had to try to resolve it among themselves. As a result, Judge O'Leary recalls, few discovery disputes reached the judges. ${ }^{104}$

\section{Settlement}

Intersystem coordination will sometimes achieve a global settlement resolving the entire hitigation. Even when judges do not actively imvolve themselves in the settlement process, coordination efforts in other areas can facilitate settlement. In the Hyatt Skywalk higation, for example, all the state and federal parties were brought together by certification of a federal class action. ${ }^{105}$ Though later vacated, the certification contributed to the achievement of a global settlement.

Many judges have come to recognize that settlement of mass tort actions in either state or federal court requires settling the cases in both systems. Judge Zampano observes that the defendants in the L'Ambiance Plaza hitigation would not have been interested in settling the federal cases had they been required to go to trial im the state cases. ${ }^{106}$ Judge Bechtle encountered the same attitude im the MGM hitigation. ${ }^{107}$ Accordingly, in several major cases, state and federal judges have combined resources to effect a settleinent of all the cases pending in both court systems. They have used a range of mecharisms for settlement coordination.

104 Interview with Judge Timothy D. O'Leary, supra note 94.

105 In re Federal Skywalk Cases, 93 F.R.D. 415 (W.D. Mo.), vacated, 680 F.2d 1175 (8th Cir.), cert. denied, 459 U.S. 988 (1982).

106 Interview with Robert C. Zampano, Senior Judge, United States District Court for the District of Connecticut, in New Haven, Conn. (May 31, 1991) (on file with the Federal Judicial Center, Washington, D.C.).

107 Interview with Louis C. Bechtle, Judge, United States District Court for the Eastern District of Pennsylvania, in Naples, Fla. (May 15, 1991) (sitting by designation in the District of Nevada) (on file with the Federal Judicial Center, Washington, D.C.). 


\section{Joint Alternative Dispute Resolution}

The L'Ambiance Plaza litigation demonstrates that alternative dispute resolution (ADR) methods may be successfully applied to related multiforum litigation. The state and federal judges collaborated in applying ADR techniques, and settled the many cases ${ }^{108}$ within eleven montlis. An analysis of their efforts provides insight into effective coordination.

Shortly after the federal cases were assigned to Judge Eginton, he spoke with Judge Zampano, the court's ADR specialist, about whether ADR was appropriate for this litigation. Although the court's ADR program liad apparently never been applied to inass tort litigation, they decided to attempt mediation.

Judge Zampano soon recognized that resolution of the cases required the involveinent of both the federal and state courts. He contacted Judge Aaron Ment, the Chief Court Administrator for the State of Connecticut, who readily agreed that coordination would be beneficial. Judge Ment subsequently assigned the state cases to Superior Court Judge Meadow for settlement purposes. Judge Zampano recalls tliat, during his initial meeting with Judge Meadow to discuss coordinated settlement efforts, they succeeded in "set[ting] up a program in our own minds," involving an "overall structure" for the mediation process. ${ }^{109}$ The first pliase involved persuading counsel not to pursue further litigation in eitler state or federal court but rather to participate fully in settlement efforts. Judge Zampano sent a letter to all parties notifying them of "a series of mediation sessions" to be conducted by himself and Judge Meadow, acting as the "L'Ambiance Plaza Litigation State-Federal Mediation Panel."110 The notice requested that all parties refrain from pretrial proceedings except those necessitated by time limitations, and stated that, although there was "no legal obligation" for them to participate in the mediation sessions, there was a "strong social and moral obligation to do so."111

108 The litigation involved a inultitude of parties. Potential defendants included the developer of the building complex, construction contractors, subcontractors, architects, engineers, and insurers, as well as the City of Bridgeport. Numerous plaintiffs filed wrongful death and personal injury suits, and some of the defendants in the tort suits became plaintiffs in contract claim actions.

109 Interview with Judge Robert C. Zampano, supra note 106.

110 Letter froin Robert C. Zampano, Senior Judge, United States District Court for the District of Connecticut, to the parties to the L'Ambiance Plaza Litigation 1 (Jan. 25, 1988) (on file with the Federal Judicial Center, Washington, D.C.).

111 Id. at 3. 
Judges Zampano and Meadow began conducting unofficial discovery of their own. Using reports resulting from several investigations ${ }^{112}$ as a starting point, they held a series of meetings with the attorneys, experts, and imsurers. Through these "get acquainted" sessions, the judges gathered information that provided a foundation for the settlement recommendations they would eventually inake. They stressed that any conclusions they reached were for settlement purposes ouly. ${ }^{113}$

Couneeticut law required the participation in the settlement process of several other jurisdictions in addition to the state and federal courts. The Connecticut Probate Court would have to approve settlement provisions in death cases, and the Workers Coinpensation Commission would have to approve settlement arrangements with workers' coinpensation carriers. ${ }^{114}$ Judge Zampano contacted the Chief of the Probate System, who, following Judge Zampano's recommendation, assigned all of the cases to one probate judge. Also at Judge Zampano's request, the Chairman of the Connecticut Workers Compensation Commission had all of the relevant cases assigned to himself and one other commissioner.

One jurisdictional overlap caused more serious complications. While the Mediation Panel's settlement efforts were getting under way, five of the L'Ambiance defendants were contesting citations and fines issued by the Occupational Safety and Health Administration (OSHA) before an administrative law judge for the Occupational Safety and Health Review Commission sitting in Boston. Those defendants expressed concern about participating in the settlement proceedings before the Mediation Panel while at the same time vigorously defending theinselves before the Commission. Judge Zampano called the judge, who agreed to stay proceedings.

After five inonths of investigation, Judges Zampano and Meadow decided to jointly interview the plaimtiffs in the death and personal injury cases to determine the mimimum amount required for a settleinent "pot." During the ensuing weeks, forty-four plamtiffs met with the judges in Judge Zampano's chambers and described the impact of the tragedy on their

112 These included investigations by the Occupational Safety and Health Administration and the Connecticut state police.

113 Judges Zampano and Meadow made no official findings of fact, nor did they decide any legal issues. As Judge Zampano recounts, "we decided that we were not going to have legal problems influence our settlement discussions." Interview with Judge Robert C. Zampano, supra note 106. Judge Zampano admits that "[t]his may seem strange coming from judges," id., but, as Judge Meadow concludes, "tle role that we played was really a quasi-judicial role." Interview with Frank S. Meadow, Judge, Superior Court of Conneeticut, in New Haven, Conn. (May 31, 1991) (on file witl the Federal Judicial Center, Washington, D.C.).

114 Sec In re L'Ambiance Plaza Litig., No. B-87-290(WWE) (D. Conn. \& Conn. Super. Ct. Dec. 1, 1988) (Special Settlement Proceedings). 
lives. ${ }^{115}$ After every interview, each judge wrote down wliat lie considered a fair settlement figure for that plaintiff. They then discussed low they arrived at the figure, and reached a consensus on an appropriate settlement amount. These figures were incorporated into forty-four separate opinions, drafted by Judge Zainpano and reviewed by Judge Meadow.

A final settlement also required resolution of property damage and contract claims arising from the collapse. Five defendants were still unwilling to settle while still facing proposed OSHA fines totalling more than five million dollars. Judges Zainpano and Meadow met several times with OSHA officers in a continuing effort to reach an agreement acceptable to both OSHA and the five defendants. OSHA eventually agreed to reduce fines to $\$ 425,000$, whicl becaine part of the settlement pot. The structure of the settlement was essentially established.

Judges Zainpano and Meadow still needed the formal approval of all jurisdictions involved. Judge Zampano planned an en masse settlement hearing involving the District Court, Superior Court, Probate Court, Workers Coinpensation Commission, and Occupational Safety and Health Review Commission. Prior to this liearing, Judge Zampano met with the participating judges and officials to discuss the procedures for convening the five forums sinultaneously. The settlement liearing was lield in the Federal Building in New Haven, and im just over three hours the L'Ambiance settlement was approved by all concerned parties, courts, and agencies, and all orders were signed by the appropriate officials. ${ }^{116}$

Many factors contributed to the successful settlement of the L'Ambiance cases. First, Judge Zainpano ensured that all cases pending in each jurisdiction were aggregated before no more than two judges or officials. Equally iniportant, these imdividuals proved willing to cooperate with the judges and officials of the otler jurisdictions.

115 The judges conducted these interviews informally, allowing the families of the deceased to bring with them photo albums, Inementos, videotapes-anything that would help thein describe their loss.

116 On December 1, 1988, the special settlement proceedings began at 9:45 a.m. with a standing-room-only audience of over 300 plaintiffs, defendants, attorneys, observers, and reporters. Judge Zampano opened the session with a presentation on the background of the cases and the proposed settlement. Afterwards, Judge Zampano and Judge Meadow took turns presenting motions to the District Court and the Superior Court, respectively. After all documents had been presented to the federal court and the state court, the floor was turned over to representatives of the various forums. They each announced their approval of the settlement and that each would go to a different area of the building during a recess to hear any party's objections. Forty-five minutes later, the courts reconvened for final comments and then adjourned at 1:00 p.m. See Lucy V. Katz, The L'Ambiance Plaza Mediation: A Case Study in Judicial Settlement of Mass Torts, 5 Ohio St. J. on Disp. Resol., 277, 322 (1990). 
Early intervention was also critical. Judge Meadow einphasizes that the parties accepted inediation because the Mediation Panel intervened early enough-before the parties had embarked on full discovery-to hold down the costs of hitigation. ${ }^{117}$ In addition, the litigants had yet to develop hostilities that might impede settlement negotiations. ${ }^{118}$

Another important factor was the priority Judges Zampano and Meadow gave the L'Ambiance mediation. During the eleven montlis of settlement negotiations, they met an average of three days a week, and during some periods worked together for five full consecutive days. ${ }^{119}$

Judge Zampano and Judge Meadow shared equally the tasks of researching cases, conducting interviews, and planning settlement strategies. Even so, Judge Zampano was able to contribute more resources to the mediation effort because lie had a larger support staff, greater financial resources, and a more fiexible docket. ${ }^{120}$ As a result, the federal court liandled most of the administrative aspects of the settleınent process. Judge Zampano, assisted by a law clerk and a secretary, organized the liearings, issued notices, and maintained records. The federal system also provided the mediation panel with a computer to facilitate mailings and record-keeping. Furtler, the federal courthouse became the leadquarters for the mediation proceedings: Judge Zampano's courtroom could accommodate group conferences more easily than smaller state courtrooms and his clianbers provided a more comfortable setting for the individual plaintiff imterviews. Finally, the federal court contributed a well-developed ADR program. ${ }^{121}$

\section{Joint Settlement Sessions}

Coordination of settlement is possible outside an ADR or otler formal process. Sucl was the case in the Ohio asbestos litigation. Altlough the judges in that case did not participate in a specific joimt mediation program, they worked together in implementing a litigation management plan for-

117 Interview with Judge Frank S. Meadow, supra note 113.

118 Id.

119 Id.

120 Judge Zampano drafted records, organized hearings, issued notices, and maintained records. He notes that "obviously it was easier for me to accept more responsibility [for] getting things out." Interview with Judge Robert C. Zampano, supra note 106. Judge Meadow says, "I had to recognize right froin the start that Judge Zampano and his staff were far better equipped than any state judge could have been equipped to [handle some aspects of the hitigation]." Interview with Frank S. Meadow, supra note 113.

121 Connecticut did not have an ADR program at the time of the L'Ambiance cases, and, according to Judge Meadow, though the state judiciary is currently developing such a program, it is still in an embryonic stage. Interview with Frank S. Meadow, supra note 113. 
mally adopted by the federal court and tracked by the state court. ${ }^{122}$ Their coordination was critical to the settlement of both state and federal cases.

The manageinent plan called for grouping federal cases into "clusters" that proceeded through a truncated discovery phase designed to gather information necessary for case evaluation and settlement negotiatious. ${ }^{123}$ To facilitate simultaneous settlement of related federal and state cases, Judge McMonagle grouped the state cases to correspond to the federal clusters. $\mathrm{He}$ and Judge Lambros participated in joint settlement sessions. They conducted "shuttle diploinacy" in settlement negotiations between the parties. Federal Judge Lambros recalls that "it was not unusual for [Judge McMonagle] to come over and spend the whole day with me in settlement negotiations," and "I would go over to his court and do the same thing." 124 At sessions in the federal court, Judge Lambros took the lead, whereas Judge McMonagle presided at sessions in the state court. Interaction at the joint sessions provided mutual reinforcement for the judges in their decisions. ${ }^{125}$ Judge Lambros also believes that he and Judge McMonagle "spoke with more authority and credibility when we were together."126 A significant number of state and federal cases have settled as a result of these joimt efforts.

\section{Supervision by One Judge or a Special Settlement Master}

In some instances, one judge has supervised settlement for both the state and federal courts. This type of arrangement may have the undesirable effect of reducing the involvement of one jurisdiction. On the other hand, concentration of authority in one imdividual often results in greater efficiency. Such an approach has proven successful in achieving global or widespread settlement in several cases.

For example, in the MGM Hotel Fire hitigation, the federal court took the lead role in a coordinated settleinent process. Judge Bechtle explained that defendants and third-party defendants considered a global settlement "the only type of settlement which [they] would be willing to enter because of the need to resolve all claims and end all hitigation, both in federal and state

122 See In re Ohio Asbestos Litig., No. OAL (N.D. Ohio Dec. 16, 1983) (Order No. 6, Establishment of the Case Management Plan and Case Evaluation and Apportionment Process).

123 Id.

124 Interview with Chief Judge Thomas D. Lambros, supra note 75.

125 Judge Lambros points out that the "exchange of views" he liad witlı Judge McMonagle was particularly helpful in complex areas, such as determining percentages of defendant liability in order to put together settlement pots. Id.

126 Id. 
court."127 After Judge Bechtle met individually with all of the federal and state plaintiffs to assess the value of their cases, a global settlement was achieved. ${ }^{128}$

The state and federal courts can also jointly appoint a special settleinent master. In the Brooklyn Navy Yard hitigation, Judge Weinstein and Justice Freedman, after consulting with other judges in their jurisdictions and holding two lengthy meetings with plaintiffs' and defendants' attorneys, issued a joint order appointing the saine individual as both referee ${ }^{129}$ and settlement master. ${ }^{130}$ Their order stressed that the "einergency nature" of the asbestos hitigation required a joint appointinent and close cooperation between the state and federal courts, and that the powers of a referee under state law and a settlement master under federal law were in this case equivalent. ${ }^{131}$ Although an all-inclusive "global settleinent" was not achieved, the efforts of the settlement master-referee and the judges helped settle inost of the claims. ${ }^{132}$

\section{Informal Settlement Coordination}

Even when settleinent efforts are not formally coordinated by the state and federal judges, informal coordimation is possible. In the Chicago air crash cases, the Federal Liaison Counsel reported that "[e]arly in the proceedings, the parties agreed that the [federal] Court would receive information on a confidential basis pertaining to all settlements or verdicts, including those outside the consolidated cases, i.e., cases filed in state court."133 The federal judges were thus privy to the ainounts for which the state cases were settling. This information helped them evaluate and recommend settlements for the federal cases and thus maintain consistency with the state cases.

127 In re MGM Grand Hotel Fire Litig., 570 F. Supp. 913, 917 (D. Nev. 1983).

128 Id. at 918-24.

129 This was done pursuant to $\S 4301$ of the New York Civil Practice Law and Rules.

130 This was done pursuant to Rule 53 of the Federal Rules of Civil Procedure. See In re Joint E. \& S. Dists. Asbestos Litig., 129 F.R.D. 434 (E. \& S.D.N.Y. \& N.Y. Sup. Ct. 1990) (joint appointenent of settlement master-referee).

131 Id. at 435; see also In re Joint E. \& S. Dists. Asbestos Litig., 737 F. Supp. 735 (E. \& S.D.N.Y. \& N.Y. Sup. Ct. 1990) (ruling that it is unnecessary to distinguish between stateappointed and federal-appointed masters or referees in applying judicial ethical standards). For a fuller description of the duties and activities of the settleinent inaster-referee in the Brooklyn Navy Yard hitigation, see Weinstein \& Hershenov, supra note 18, at 301.

132 Weinstein \& Hershenov, supra note 18, at 301 . Trials against the "hold-outs" proceeded independently in the state and federal courts. Id.

133 Airline Disaster Litig. Report, supra note 93, at 413. 


\section{Settlement-Related Coordination}

Some judges have used outside specialists to handle settlement-related matters. For example, in the Beverly Hills Supper Club hitigation, the federal and state judges appointed co-trustees to deposit the settlement funds into a federally insured institution (as opposed to court registries) so that the plaintiffs would receive interest. The trustees worked closely together, though they maintained separate accounts for state and federal settlements. ${ }^{134}$ In the L'Ambiance Plaza hitigation, the state and federal courts appointed a settlement administrator to "facilitate and implement . . . all of the settlement agreements." 135

\section{Joint Pretrial Hearings}

Joint hearings presided over by both the state and federal judges are useful during various phases of hitigation. In addition to joimt hearings held for discovery and settlement purposes, as discussed above, judges have used them at the outset of hitigation to establish a jomt case management framework ${ }^{136}$ or to hear motions involving substantive matters such as class certification or summary judgment.

Joint hearings may be an integral part of the hitigation scheme or simply an efficient method of handling a particular matter. In some cases, judges conducted numerous joimt hearings, completely coordinatimg their related htigation. Early in the Beverly Hills Supper Club hitigation, Judge Rubim recognized the complexity of the case and suggested to Judge Diskin that they handle it together. They sat together every few months to handle pending matters. Justice Freedman and Judge Weinstem managed the Brooklyn Navy Yard cases in much the saine way. Joint hearings often serve more limited purposes. In the Exxon-Valdez hitigation, for example, the judges conducted two joint hearings: one to determine the structure of overall coordination and the other to resolve motions regarding state and federal class certifications. ${ }^{137}$

134 Interview with Judge Carl B. Rubin, supra note 72.

135 In re L'Ambiance Plaza Litig., No. B-87-290(WWE) (D. Conn. \& Conn. Super. Ct. Dec. 1, 1988) (Special Settleinent Proceedings, appointing Arthur S. Sachs as "special master" under federal law and as "committee" nnder Connecticut state law).

136 Early in the Exxon-Valdez litigation, Judges Holland and Shortell inet with all of the attorneys involved in the civil cases to arrange a joint state-federal discovery plan and to assess the potential for further coordination. Similarly, in the Ohio asbestos hitigation, Judges Lambros and McMonagle held joint hearings to determine whether joint state-federal special masters could be appointed to develop a structure for the hitigation.

137 See also Calvert Fire Ins. v. Will, 560 F.2d 792 (7th Cir. 1977) (state and federal judges held joint oral argument on the issue of whether a participatory interest in a reinsurance pool constituted a "security"). 
Judges have found that joint hearings achieve many of the benefits of consolidation before one judge while maintaining the involvement and preserving the distinct interests of both the federal and state courts. Most obviously, joint hearings conserve time and resources by avoiding duphication. As one judge explains, "What conceivable sense is there in having ... lawyers appearing in two separate courts doing the saine thing twice?"138 Joint hearings also enable judges to share information, insights, and even case management techinques, all of which can help expedite litigation.

Joint hearings serve other purposes as well. In the Ohio asbestos hitigation, Judge Lainbros found joint hearings helpful in introducing the lawyers to the "new cultural setting" of state-federal coordination. ${ }^{139}$ The judges wanted to deinonstrate the degree of cooperation they hoped to achieve and to inake the lawyers comfortable working with both judges. Furthermore, they wanted to encourage the lawyers to work together. ${ }^{140}$ Coordinating the state and federal cases, Judge Lambros says, "was a good strategy to get lawyers to cooperate and to realize that we were concerned with avoiding duphication."141 He notes that the visible cooperation between the state and federal systeins gave the two judges "clout" that "got the attention of the lawyers." 142

Two overlapping aspects of jomt hearings require further exploration: the nuts and bolts of arranging and conducting such hearings, and the kinds of conflicts that can arise and the ways courts have dealt with them.

\section{The Mechanics of Joint Hearings}

Joint hearings require planning to determine such logistical matters as location, who will preside, the issues to be addressed, and the conduct of the hearing. Soinetimes this can be accoinplished through regular contact in the course of the hitigation. Judges Eginton and Healey, for example, sorted out the logistics of pretrial matters for the L'Ambiance Plaza hitigation over two lunches. Sometimes inore extensive preparation is necessary. Before each joint hearing conducted in the Brooklyn Navy Yard cases, Judge Weinstein drafted an agenda and sent it to Justice Freedman, who would make additions. Some preparation can take place just before a hearing; Judges Eginton

138 Interview with Carl B. Rubin, supra note 72.

139 Interview with Thomas D. Lambros, supra note 75.

140 Judge McMonagle recounts that the lawyers had not been cooperating among themselves: The "vast majority were provincial in their approach . . . [a]sserting rights of individuals." Interview with James J. McMonagle, supra note 72. They also were unfamiliar with the types and numbers of asbestos cases inushrooming on state and federal dockets.

141 Interview with Thoinas D. Lambros, supra note 75.

142 Id. 
and Healey met in chambers immediately prior to each of their two joint hearings.

Selecting the loeation for a joint hearing is not always a simple inatter. For example, the judges in the Beverly Hills Supper Club litigation originally planned to hold the joint hearings in the United States courthouse in Kenton County, Kentucky, but then decided to use the state courthouse when a lawyer questioned whether the state court's jurisdiction extended beyond the geographical boundaries of its circuit. The hearings were, however, later moved to the more spacious federal courtrooms and no one objected.

Although one system's courtrooins inay be significantly larger and better equipped than the other's, there inay be symbolic value to holding joint hearings in both courts. In the L'Ambiance Plaza litigation, Judge Eginton would rather have held all joint hearings in the state courthouse, but felt that for "public image" it was important to hold the hearings in both the state and federal courthouses. ${ }^{143}$ Similarly, Judge Lambros suggested that his first joint hearing with Judge McMonagle in the Ohio asbestos hitigation be held at the state court because he "didn't want to create the impression that the federal judge ... was attempting to dominate the process." 144 Instead, he wanted to demonstrate that they "were functioning as equal entities."145 The judges held their next joint hearing in the federal court. In general, except where one system's courtrooins were significantly better suited to large meetings, judges have alternated between the courtroons of both jurisdictions. ${ }^{146}$

Another inatter that the judges should address at the outset is the services of court employees. In the Beverly Hills Supper Club litigation, representatives froin both courts were present at the hearings. In the L'Ambiance Plaza litigation, the judges einployed the state court deputy, bailiff, and court reporter for hearings conducted in the state court and their federal counterparts for hearings in the federal court. Addressing this issue well in advance of the hearing can help head off labor disputes.

The actual conduct of joint hearings varies substantially. Judges must develop a pattern of conduct with respect to inany small matters, such as what to do when it becomes necessary to confer with one another. Judges Eginton and Healey retired to chambers when the need arose. Other judges

143 Interview with Warren W. Eginton, Judge, United States District Court for the District of Connecticut, in New Haven, Conn. (July 15, 1991) (on file with the Federal Judicial Center, Washington D.C.)

144 Interview with Thomas D. Lambros, supra note 75.

145 Id.

146 In the Brooklyn Navy Yard litigation, hearings were leld in various locations, including the federal and state courthouses and the Federal Court of International Trade in Manhattan. 
quietly consulted while remaining on the bench. A larger question concerns the nature of the collaboration. In the Beverly Hills Supper Club hitigation, the judges were determined to collaborate as equals at every step. Judge Rubin recalls that "we would simply sit together on the bench and as these motions were heard we would each ask questions and when we were finished we would get together and decide what to do."147 In both the Ohio asbestos litigation and the Brooklyn Navy Yard hitigation, the judge in whose courtroom the hearing was conducted would preside. Regardless of who was presiding, botlı judges posed questions and were actively involved. ${ }^{148}$

The extent of collaboration in the decisionmaking process has varied as well. In most instances, the judges have reached a consensus before issuing rulings. ${ }^{149}$ There are also several ways for the judges to approach the drafting of the courts' rulings. In the Beverly Hills Supper Club litigation, because Judge Rubim had a larger staff than Judge Diskin, lee prepared drafts of orders. The drafts were then forwarded to Judge Diskin who made any amendinents that he deemed necessary before filing the state order. In other cases, such as the Exxon-Valdez hitigation, both the state and federal judges drafted orders that were exchanged for suggested revisions. The judges then either issued separate orders or blended their drafts into a single order.

Of course, judges will not always be able to agree on the outcome of each issue, especially in cases where the state and federal courts must apply different law. We now turn our attention to the kinds of difficulties that can arise during joimt hearings, and how they can be managed.

\section{Resolving Conflicts}

One might expect joint state-federal hearings to encounter insuperable problems because of differences in the rules or procedures of the state and federal courts. In fact, such problems have been rare. State and federal rules are often similar if not identical. ${ }^{150}$ Even where they differ, however, judges have been able to work within both sets of rules to resolve disputes. "Federal rules are essentially equity based," says Judge Weinstein, and pro-

147 Interview with Carl B. Rubin, supra note 72.

148 Interview with Helen E. Freedinan, supra note 75. In the Brooklyn hitigation, on the few occasions when one judge could not attend a hearing, the other conducted the proceeding. Rulings were subsequently ratified by the absent judge. Id.

149 In the Beverly Hills, Brooklyn Navy Yard, and L'Ambiance Plaza cases, the judges discussed the arguments, arrived at mutually satisfactory conclusions, and issued consistent rulings. In Beverly Hills and L'Ambiance Plaza, they issued the same orders under separate captions. Justice Freedman and Judge Weinstein went further, issuing joint rulings under both courts' captions. See, e.g., In re Joint E. \& S. Dists. Asbestos Litig., 129 F.R.D. 434 (E.D.N.Y., S.D.N.Y. \& N.Y. Sup. Ct. 1990) (jointly appointing settlement master-referee).

${ }^{150}$ See supra text accompanying notes $97-102$ (discussing absence of disputes over discovery and noting similarity of state and federal rules). 
vide judges with "wide discretion."151 Judge Weinstein also beheves that state law imposes few limitations, noting that New York state law did not substantially limit his coordination efforts with Justice Freedinan. ${ }^{152}$ According to Judge Weinstein, "given the flexibility of the state and federal practice and with the ingenuity of the judges and parties, there isn't any problein [caused by conflicting rules] that can't be solved, or someone has misinterpreted the law."153

Even where the state and federal rules are identical, or the differences between thein are bridgeable, judges might nevertheless disagree over the application of the rules in a particular case. In the Brooklyn Navy Yard cases, for example, Judge Weinstein and Justice Freedman sometimes disagreed about summary judgment motions. They resolved these disagreements by liaving the judge who had jurisdiction over the particular case render the deeision. This remams an option for state and federal judges who cannot reach a consensus: each can issue orders pertaining to his or her own case. In the Exxon-Valdez litigation, Judges Holland and Shortell conducted a joint learing to determine whether or not to certify class actions. After learing the plaintiffs' argument on certification, Judge Holland denied their motion. Judge Sliortell, lowever, cliose to take the matter under adviseinent rather than ruling at that time, and later certified several classes.

There is potential for disagreement whenever judges work together-as on appellate panels, for example. The relationship between state and federal judges is furtlier complicated by the different institutional positions oceupied by the judges, although this can often facilitate coordination. In most instances of related multiforum hitigation, the state and federal courts apply the same substantive law-ordinarily state law-and the federal judges generally defer to the state court on state law issues. ${ }^{154}$ Judge Rubin believes that "this matter of deference . . . is critically important" to state-federal coordimation. ${ }^{155}$ Deference to the state judge's interpretation of state law not only draws on the judge's expertise but also ensures state court involvement in a process that miglit otherwise be dominated by the federal court. ${ }^{156}$

151 Interview with Jack B. Weinstein, supra note 75.

152 Id.

153 Id.

154 Few judges recalled disputes in interpretation of state law, perhaps in part a function of this deference. Judge Rubin, for example, reports that he often deferred to Judge Diskin on issues of Kentucky law, in part because Judge Diskin was more familiar with its "peculiarities." Interview with Carl B. Rubin, supra note 72.

155 Id.

156 For a discussion of thc appropriate extent of such deference, and of state judges deferring to federal judges on issues of federal law, see infra text accoinpanying notes 253-66. 
Deference will reduce but not automatically eliminate conflict between state and federal judges. Direct conflict may be avoided by eschewing joimt hearings-at least where a conflict seems likely. For this reason, Judge Lambros and Judge McMonagle made a point of not holding joint hearings dealing with evidentiary matters or controlling issues. Even when joimt hearings result im divergent rulings, however, they may offer benefits such as greater judicial economy, the added experience and insight of a second judge, and the promotion of future cooperation. ${ }^{157}$ Thus, although disagreements arose, none of the judges in either the Exxon-Valdez or Brooklyn Navy Yard hitigation regrets conducting the joint hearings. ${ }^{158}$

Communication im the face of disagreement is critical. Judge Holland emphasizes that although he and Judge Shortell have sometimes gone im different directions in the Exxon-Valdez litigation, they have not diverged without first discussing what each of them was about to do. ${ }^{159}$ Furthermore, they have not permitted their disagreements to interfere with their cooperation in other areas. Judge Holland explaims that if an issue "comes up tomorrow that is the subject of a motion that is filed in both [courts], we are going through the same drill that we have had before of having [a] joimt hearing [ ] if a hearing is needed [a]nd conferring with one another on a decision to see if we can reach a decision that is acceptable to both of us."160

Fimally, cooperation among the judges in a joint hearing will influence the general tone and atmosphere of the procceding and may promote enhanced cooperation among the attorneys involved. Such cooperation among counsel is extremely helpful and greatly improves the likelihood of a successful hearing because, as Judge Wcmstem notes, attorneys who are enthusiastic about coordination can alleviate procedural or logistical difficulties associated with state-federal proceedings. ${ }^{161}$

157 See supra text accompanying notes $136-42$.

158 See Interview with H. Russel Holland, supra note 74 (Exxon-Valdez litigation); Interview with Brian C. Shortell, Judge, Alaska Superior Court (July 10, 1991) (on file with the Federal Judicial Center, Washington, D.C.) (same); Interview with Jack B. Weinstein, supra note 75 (Brooklyn Navy Yard litigation); Interview with Helen E. Freedman, supra note 75 (same).

159 Interview with H. Russel Holland, supra note 74.

160 Id. That the judges reaclied different conclusions with respeet to class certificationcreating certain probleıns for the hitigants-did not diminish the value of coordination to the extent that it reduced conflict and inconsistency. Id.

161 Interview with Jack B. Weinstein, supra note 75. For example, cooperative attorneys can stipulate to certain proeedures regardless of differences between state and federal courts. See, e.g., Interview with Peter T. Fay, supra note 100 (noting that attorneys could stipulate to using the same six people as jurors for both the federal and state cases in a joint trial). 


\section{E. Joint Trials}

The inost advanced stage of state-federal cooperation would involve a joint trial. The Manual for Complex Litigation encourages judges to consider this kind of arrangement, ${ }^{162}$ and the potential benefits are clear. Like joint hearings, joint trials may be more efficient because the parties are required to adduce evidence only once. A joint trial, like a joint hearing, would also enable judges to benefit from one another's insights and information.

Despite these advantages, none of the judges we interviewed conducted a joint trial, which suggests that such trials may be impractical. ${ }^{163}$ However, in several cases - the Hyatt Skywalk, Florida Everglades, and Brooklyn Navy Yard litigation - the state and federal judges considered conducting a joint trial. ${ }^{164}$ Moreover, in many respects joint trials would resemble joint hearings, and the same arrangeinents that have proven feasible in joint hear-

162 Manual for Complex Litigation, Second § 31.31 (1986).

163 A joint trial clearly cannot occur absent agreement of the judges on numerous matters, such as the order in which issues should be tried. In the Brooklyn Navy Yard hitigation, for example, the judges decided not to conduct a joint trial, in part because they disagreed about how the cases should be tried-Justice Freedman favored a reverse-bifurcation procedure, whereas Judge Weinstein preferred to try all issues at once. The judges must also agree how to structure the plaintiff class. In the Hyatt Skywalk cases, the judges could not agree on this point. Similarly, Judges Holland and Shortell disagreed about whether class certification was in order in the Exxon-Valdez hitigation.

164 See Interview with Timothy D. O'Leary, supra note 94 (Hyatt Skywalk litigation); Interview with Peter T. Fay, supra note 100 (Florida Everglades hitigation); Interview with Jack B. Weinstein, supra note 75 (Brooklyn Navy Yard litigation). Most judges agree that although a joint trial may be appropriate on the issue of hability, it would not be feasible on the issue of damages because of the individual nature of plaintiffs' damages and the difficulty of determining and allocating damage awards when two juries are involved.

In the Brooklyn Navy Yard cases, Judge Weinstein and Justice Freednnan planned to preside over a joint trial. In the pretrial phases, the state and federal judges closely coordinated their cases-adopting similar case inanagement plans, placing double-filed cases on parallel tracks, providing for common depositions, and faxing orders to each other to inaintain consistency. (Judge Sifton was in charge of the federal cases before transferring them to Judge Weinstein. See supra text accompanying note 68.) At the trial phase, however, the state and federal cases proceeded independently, resulting in repeated adjudication of the same issues and a bottleneek in both the state and federal systeins. To anneliorate this situation, Judge Weinstein proposed a consolidated state-federal trial of cases involving exposure at the Brooklyn Navy Yard, and Justice Freedman concurred. They presided over joint hearings and issued coununon rulings, and set the stage for a joint trial, with two separate juries, to be held in September 1990. Interview with Jack B. Weinstein, supra note 75; In re Joint E. \& S. Dists. Asbestos Litig., 737 F. Supp. 735, 747 (E.D.N.Y., S.D.N.Y. \& N.Y. Sup. Ct. 1990). The judges ultimately decided not to conduct a joint trial, both because a large number of defendants had settled (rendering a joint trial unnecessary) and because the judges came to believe that practical problems would render a joint trial unworkable. Interview with Jack B. Weinstein, supra note 75; Interview with Helen E. Freedinan, supra note 75. 
ings ${ }^{165}$ might work in a joint trial as well. Judge Fay, who handled the federal cases in the Florida Everglades hitigation, beheves a joint trial could be relatively straightforward and easy to conduct:

[W]e had decided that there was no reason why the two of us couldn't sit on a bench, [e]ven to the point where one of us might preside in the inorning and the other would preside in the afternoon. ... [W]e would have a jury of six people sitting as a federal jury and a jury of six people sitting as a state jury.

... I'1n sure if we had had the trial we wouldn't have had any probleins .... ${ }^{166}$

Although other judges inay not share Judge Fay's optimism, several nevertheless look favorably on the possibility of a state-federal trial. One remarks that it would be "fascinating" and would "require a great deal of ingenuity."167 (Judges Fay and DuVal developed a systein of "signals" they could use to communicate whether they were inclined to sustain or overrule an objection.) Another notes that attorneys have also reacted favorably to the idea of a joint trial, ${ }^{168}$ and are imtrigued by its novelty and interested in at least attempting to participate in one. Indeed, in the Hyatt Skywalk hitigation, five attorneys representing state and federal plaintiffs filed a motion in the state and federal courts requesting a joint trial. ${ }^{169}$

Soine parties might fear that their claims will receive short shrift if tried jointly with claims in another court system. Judge Fay, for one, insists that such a concern is unfounded:

I was their federal judge and they were going to have a federal trial. We weren't going to eliminate anything.

... [T]here was no reason that all these hitigants wouldn't have all their rights. ... . [The federal litigants] would have a trial in federal court. [The state hitigants] would have a trial in state court. It was just that we were going to do it all at once. ${ }^{170}$

165 See supra text accompanying notes 136-61.

166 Interview with Peter T. Fay, supra note 100.

167 Interview with Carl B. Rubin, supra note 72.

168 Interview with Peter T. Fay, supra note 100.

169 See Mary K. Hopkins, Kenneth E. Nelson, James R. Pietz \& Phyllis Raccuglia, A Case Study in Mass Disaster Litigation, 52 U.M.K.C. L. Rev. 151, 170 (1984). Their motion was denied by the federal court and not considered by the state court. Id.

170 Interview with Peter T. Fay, supra note 100. 
Assuming that joint trials are indeed feasible, they likely would encounter probleins. The potential logistical and practical complications, for example, labor disputes arising from the assignment of court personnel, are manifold but stem mostly from the need for separate juries im the state and federal cases. ${ }^{171}$ Most of the judges who liave contemplated jomt trials envision two juries in the courtroom-one for the state cases and one for the federal cases. Judge Fay notes that the attorneys could stipulate that the same people may serve as both the state and federal jury, ${ }^{172}$ but the general view is that two separate juries are necessary. When conflicts between state and federal rules arise, all parties must be guaranteed the protection of the system in which their case is heard. The state rules may permit certain testimony that the federal rules do not. The use of two separate juries would allow the federal court to excuse the federal jury during such testimony. Having two juries ensures that the state and federal judges each retain control over their cases by allowing them to pursue different paths-through different instructions or admonitions, for example. With a single jury, one judge miglit have to defer to anotlier's rulings or face unresolvable conflicts. In addition, altlough a federal jury must be unanimous to return a verdict, ${ }^{173}$ inany states do not require unanimity. ${ }^{174}$

A "two jury" approach creates coniplications of its own, however. Some are purely logistical natters-two juries niay place a strain on the limited accommodations of a courtroon1, and one juror's illness will cause delays im both jurisdictions. Numerous other problenis sten from differences between state and federal law. State and federal jury selection procedures are often "worlds apart."175 As a result, it could take mucl longer for one court to select a jury than for the other, which would delay the trial in the faster court. Similarly, states may differ with the federal systen 1 as to the availability of niterlocutory appeals during trial. ${ }^{176}$ Conflicts between state and fed-

171 Thus, a number of judges point out that a joint bench trial is far more feasible than a joint jury trial. See, e.g., Interview with H. Russel Holland, supra note 74 (noting that problems involved in a joint trial would be "even worse [in] a jury trial"). However, im multiparty litigation, some litigants will almost invariably invoke the right to a jury.

172 Interview with Peter T. Fay, supra note 100.

173 Fed. R. Civ. P. 48.

174 See, e.g., La. Const. art. I, § 17; Or. Const. art. I, § 11.

175 Letter from James T. Healey, State Trial Referee, for the Connecticut Superior Court, to Nancy E. Weiss, Federal Judicial Center (July 23, 1991) (on file witl the Federal Judicial Center, Washington, D.C.) (discussing possible procedures and problems involved in a joint state-federal trial in the L'Ambiance Plaza litigation).

176 Althougl interlocutory appeals may prove beneficial when a ruling on a state issue is necessary, the delay caused by such constant interruptions may further complicate joint proceedings. 
eral rules of evidence may present the greatest difficulty. ${ }^{177}$ Although one jury may be sent out of the courtroom so that evidence can be introduced before the other jury, this process can cause confusion and delay. Further, the process of presenting different evidence to separate juries will not be uncontroversial. Even if one jury is dismissed while certain evidence is presented, the circumstances surrounding the jury's excusal may create an impression that influences that jury. This may result im additional appeals that frustrate the goal of greater judicial economy.

These problems may not be insoluble. Both Judges Fay and Weinstein, for example, are confident that removing one jury from a courtroom while evidence is presented to the other could work relatively smoothly. ${ }^{178}$ Moreover, Judge Weinstem beheves that such action will generally not be necessary because the federal and state rules grant judges a substantial measure of discretion. ${ }^{179}$ Justice Freedman agrees that a joint trial could work, but emphasizes that, as a general matter, such efforts would work best for short trials. ${ }^{180}$ She came to believe that a joint trial would have been extremely difficult in the Brooklyn Navy Yard cases due to the number of parties involved, the differences im state and federal procedures, and the problems of managing the two juries. ${ }^{181}$

The use of two juries also presents the risk of inconsistent verdicts. This particularly concerned Judge Wright, who consequently opposed conducting a joint trial in the Hyatt Skywalk hitigation. ${ }^{182}$ Inconsistent verdicts reduce public confidence in the jury system by dispelling the notion that there is a single proper resolution to all issues that would be arrived at by any jury hearing a particular matter, In addition, such verdicts would be regarded as unjust by the parties adversely affeeted.

Arguably, this is primarily a problem of appearances. As noted above, the state and federal juries may be exposed to different evidence, follow different procedures, and apply different rules of law. In such a situation, divergent verdicts may be easily justified. Even if the state and federal juries are exposed to the same evidence under the same or similar rnles of law, however, different verdicts might still emerge. In a mock trial of ten cases con-

177 For example, federal rules are generally much more hiberal than state rules with respect to the admissibility of summaries of depositions and documents.

178 Interview with Peter T. Fay, supra note 100; Interview with Jack B. Weinstein, supra note 75 .

179 Interview with Jack B. Weinstein, supra note 75.

180 Interview with Helen E. Freedman, supra note 75.

181 Id.

182 "[T] verdicts [which would be a] disaster." Interview with Scott $O$. Wright, Senior Judge, United States District Court for the Western District of Missouri, in Kansas City, Mo. (July 19, 1991) (on file with the Federal Judicial Center, Washington, D.C.). 
ducted by Judge Lambros to facilitate the settlement of asbestos claims, two separate jury panels heard arguments simultaneously, but deliberated independently. One of the juries found none of the defendants hable, while the other found for the plaintiffs im six of the cases, holding almost all of the defendants hable for several million dollars in damages. ${ }^{183}$ This problem, however, is not unique to joint federal-state trials. Absent complete consolidation, similarly situated parties in any mass hitigation inay receive different treatment. It is already the case that separate trials on virtually identical issues and evidence produce disparate results. ${ }^{184}$ The problein is more visible, but not otherwise different, when the mconsistency occurs in a single trial.

Until joint trials are attempted, it is impossible to say whether they are viable and, if so, desirable. ${ }^{185}$ Even if they are regarded as unworkable, it does not follow that state-federal coordination cannot oceur in the trial phase of hitigation. In the Beverly Hills Supper Club hitigation, for example, because of the large nuniber of defendants, the state and federal judges divided the hitigation into groups of cases comprising different types of defendants. ${ }^{186}$ The first three groups were tried in federal court and the fourth in state court. ${ }^{187}$ Several defendants in the federal case sought a writ

183 See Rich Arthurs, Summary Trial Fails to Prompt Tort Settlement, Legal Times, Nov. 19,1984 , at $1,7$.

184 See supra note 14.

185 Joint trials with two juries have been conducted intrasystem, im both the state and federal systems, albeit usually in criminal cases. Such trials have been upheld against various challenges. See, e.g., United States v. Rimar, 558 F.2d 1271, 1273 (6th Cir.) (simultaneous prosecutions before two juries did not create atmosphere so confusing as to deprive defendants of a fair trial), cert. denied, 434 U.S. 984 (1977), and cert. demied 435 U.S. 922 (1978); Umited States v. Sidman, 470 F.2d 1158, 1168-70 (9th Cir. 1972) (two-jary trial allowable under federal courts' authority to fashion new procedures that facilitate proper fact-finding), cert. denied, 409 U.S. 1127 (1973); Pcople v. Brooks, 285 N.W.2d 307, 308-09 (Mich. Ct. App. 1979) (dual jury did not deny defendant a fair trial despite " "traffic jams' in the courtroom," jurors sitting outside the juror box, and other logistical problems). One federal court empaneled two juries for a civil trial involving related complex, multiparty cases governed by conflicting California and Colorado law, Martin v. Bell Helicopter Co., 85 F.R.D. 654, 656 (D. Colo. 1980), but the cases settled prior to trial. See also Alex A. Gaynes, Two Juries/One Trial: Panacea of Judicial Econony or Personification of Murphy's Law?, 5 Am. J. Trial Advoc. 285, 288-91 (1981) (discussing costs and benefits of a two-jury federal crimmal trial as illustrated by United States v. Hanigan, No. CR-79-206-TUC-RMB (D. Ariz.)).

186 Interview with Carl B. Rubim, supra note 72.

187 The possibility of joint trials was not raised at the time; rather, the judges arranged to preside independently over the separate pieces of litigation. Judge Rubin recalls proceeding first in federal court because, anong other things, the federal jury is selected from a larger geographical area-he did not want to place the defendants at a disadvantage before a local jury well-infornied about and possibly affected by the tragedy. Interview witl Carl B. Rubin, supra note 72. 
of mandamus ordering their cases postponed until the state cases were decided. In denymg the writ, the Sixth Circuit noted that the state and federal judges seemed

sensitive to the issues of federalism and considerations of comity which are presented in this case. They have held hearings jointly on some pre-trial motions and are cooperating in establishing discovery and trial scliedules. ... The federal and the state judges appear to be coordinating their activities so as to avoid conflict between the two judicial systems. ${ }^{188}$

\section{F. Conclusion: The Benefits of Coordination}

Judges attempted intersystem coordination because they beheved it would promote economy, efficiency, and consistency. ${ }^{189}$ The foregoing discussion mdicates that intersystem coordination has proven effective $\mathrm{m}$ accomphishing these goals.

Beyond doubt, coordination achieved major gains in efficiency and economy. Significant sliaring of human and material resources took place in most of the cases studied, ${ }^{190}$ reducing hitigation costs, delay, and judicial timie and effort. ${ }^{191}$ Judges also benefitted from each other's expertise, ideas, information, and techinques. ${ }^{192}$ In some cases, the benefits were extraordinary. Federal-state coordination led directly to a global settlement of the

188 Union Light, Heat \& Power Co. v. United States Dist. Court, 588 F.2d 543, 544 (6th Cir. 1978), cert. dismissed, 443 U.S. 913 (1979).

189 See supra text accompanying notes 72-77.

190 State judges generally have fewer resources at their disposal. In addition to having a larger support staff, federal judges can appoint magistrates to handle aspects of their cases and have greater access to special masters to handle discovery and settlement. They also have greater access to coniputers and other support facilities. Furthermore, most federal judges, though often overworked themselves, consider their dockets niore flexible than those of their state counterparts. For these reasons, in niany of the cases, the federal court contributed greater time and resources to the hitigation. According to Judge Rubin, "[s]tate [c]ourt judges ... are terribly overworked. They are overworked, they are underpaid, they are understaffed, and I really had far more time and personnel [with which to nuanage the litigation]." Interview with Carl B. Rubim, supra note 72.

191 Sone judges say these cooperative ventures not only prevented duplication but also quickened their pace. Justice Frecdinan reports that she and Judge Weinstem were able to issue niany more rulings than usual from the bench. Interview with Helen E. Freedman, supra note 75.

192 In addition, when judges bcconre acquainted, so do their staffs. One result, says Judge Lambros, is that staffs can "avoid conflicts in scheduhing and other nuatters between the state and federal court." Interview with Thoinas D. Lambros, supra note 75. 
L'Ambiance Plaza litigation. ${ }^{193}$ In other cases, the process of judges sharing information, conferring about legal matters, and ruling jointly leelped prevent grossly disparate outcoines in the state and federal cases.

Intersystem coordination is a proven metlod of alleviatimg the burdens mass litigation imposes on the litigants and the judicial system. The judges we interviewed uniformly believe that collaboration with their state or federal counterpart proved worthwhile. Many judges expressed a vision of the courts as a unified system and a "national resource," and thus regarded intersystem coordination as a natural process in the effort to improve the administration of justice. ${ }^{194}$

\section{EfFective CoORdination: AN OVerview}

This Section discusses a wide range of issues relevant to the achievement of effective intersystem coordination: low judges might imitiate and maintain contact with one another; the necessity of establishing a strong working relationship; the role attorneys can play; the kinds of situations most conducive to coordination; and the federalism concerns implicated by state-federal coordination.

\section{A. Initiation of Contact}

\section{Timing}

Coordination obviously cannot take place until a judge contacts his or her counterpart in the other judicial system. Some judges prefer not to initiate contact until they lave systems in place and can offer tangible resources to the other court. For example, in the MGM litigation, Judge Beclitle did not approach Judge Thompson until the federal court had developed a sclieme for liandling the cases. According to Judge Bechtle, "I felt that until I really had something to offer to [Judge Thompson], I would not be doing much other than a courtesy call, which might liave been misunderstood." ${ }^{195}$ The majority of judges imterviewed, however, preferred early contact so that the

193 Judge Meadow believes that, absent a joint state-federal mediation structure, the L'Ambiance Plaza settlement process would lave "blown apart." Interview with Frank S. Meadow, supra note 113.

194 See, e.g., Interview with Peter T. Fay, supra note 100; Interview with Jack B. Weinstein, supra note 75. See generally, William H. Rehnquist, Welcoming Remarks: Conference on State-Federal Judicial Relationships, 78 Va. L. Rev. 1657 (1992) (viewing state and federal courts as one resource which sliould be used wisely and efficiently so as to reduce the present caseload crisis).

195 Interview with Louis C. Bechtle, supra note 107. 
state and federal judges could coordinate their schedules, consider joint discovery, and begin thinking about greater cooperation. ${ }^{196}$

As a general rule, contact at the earliest possible time is desirable. ${ }^{197}$ Absent such contact, it is impossible to know when and what coordination can take place. Moreover, the most extensive cooperation has been achieved primarily during discovery and other early stages of litigation.

\section{How and Who}

Most judges initiate contact througl a simple telephone call that often leads to a ineeting-generally over luncl -to discuss the litigation. All of the judges interviewed agree that the initial meetings should be infornal. ${ }^{198}$ The judges are forging an unusual working relationship, and it is critical that they become coinfortable witl one another.

Federal judges have usually initiated the contact. Soine federal judges believe they are obligated to do so because state judges inay be intimidated by their federal counterparts. ${ }^{199}$ The federal judge can facilitate effective coordination if he or slie puts the state judge "at [his or her] ease that the federal courts are not going to [rum] rouglislod over the whole thing.,"200 In this regard it can be useful for the federal judge to make the first contact. That is not to say that federal judges inust initiate contact. In the Brooklyn

196 Two to three weeks after receiving the Sioux City cases, Judge Conlon contacted Judge O'Connell to "open lines of communication" concerning coordination of their proceedings. Interview with Suzanne B. Conlon, Judge, United States District Court Judge, Northern District of Illinois (May 8, 1991) (on file with the Federal Judicial Center, Washington, D.C.). Judge Rubin contacted Judge Diskin as soon as he learned that there was a Beverly Hills case filed in state court that paralleled those in his court. Interview with Carl B. Rubin, supra note 72. Judge Holland even stayed discovery in the Exxon-Valdez litigation so that he could contact Judge Shortell and develop a state-federal pretrial and discovery scheine.

197 As Professor Frances McGovern observes, "the sooner the cooperative effort begins in the litigation, the larger the role of that cooperation. Courts that have taken control of a case before the interests of attorneys, judges, and others have becoine vested, have much more opportunity to fashion an agreeable approach." Francis E. McGovern, Conference Paper presented at National Conferenee on Emerging ADR Issues in State and Federal Courts (April 19, 1991) (on file with the Federal Judicial Center, Washington, D.C.). This certamly was true for Judges Zampano and Meadow, who attribute their success with the L'Ambiance Plaza litigation to early intervention. See supra text accompanying note 117.

198 Judge Becthle recalls first speaking witl Judge Thompson, and then walking to the Nevada state court to neet hin. Interview with Louis C. Bechtle, supra note 107. Judge Thompson responded by inviting the federal judge, along with the federal magistrate involved in the litigation, to his home for dinner where the three discussed the case at length. Interview witl J. Charles Thompson, supra note 73.

199 Interview with Louis C. Bechtle, supra note 107. Judge Rubin warns against federal judges contributing to this sense of intinidation by trying to dominate the process.

200 Interview with Carl B. Rubin, supra note 72. 
Navy Yard litigation, Justice Freedman first teleplioned Judge Sifton to discuss whetlier the two court systems could work together.

In several of the cases we studied, the judges knew each other well, which facilitated their working relationship. ${ }^{201}$ It would, however, be a mistake to infer that effective coordination requires a previous relationship. In many of the cases we studied, the judges did not know each other previously. ${ }^{202}$ Judges may be reluctant to contact another member of the judiciary whom they do not know to discuss their cases. Experience teaches that overcoming that reluctance is wortliwhile.

It should be empliasized that the mitial meeting does not commit the judges to extensive coordimation. ${ }^{203}$ Moreover, an excliange of ideas may later bear fruit even if it is originally determined that coordination is not feasible. In the Technical Equities hitigation, the state and federal judges originally did not arrive at a method of coordinating their proceedings. However, later in the hitigation they agreed to appoint cominon special masters to give consistent treatinent to the state and federal cases.

\section{B. Maintaining Contact}

The judges' initial conversations tend to focus on general perspectives of the litigation, case management strategies, and areas appropriate for statefederal cooperation. As the cases progress, the judges need to maintain contact on a range of matters mcluding sclreduling, siniply keeping abrcast of cases in the other system, preparing for joint hearings, making joint rulings, or consultimg on matters of procedure or substantive law.

To a certain extent, the amount and frequency of contact is a matter of individual preference, although much of it is tied to the stage the litigation is in, the amount of state-federal coordination, and other particulars of the case. For the majority of judges, monthly or bi-monthly contact sufficed. According to Judge Rubin, who engaged im extensive coordimation with Judge Diskin, constant communication is "far less necessary than you inight

201 Judge Lambros had met Judge McMonagle at bar association meetings. Judge Eginton states that "[Judge Healey] was an old friend, ... . so I knew ... [he] would take the same approach that I took [in managing the litigation]." Interview with Warren W. Eginton, supra note 143. Judge Fay had tried cases in Judge DuVal's court and developed a friendship with him. Interview with Peter T. Fay, supra note 100.

202 Judge Rubin recalls telephoning Judge Diskin and introducing himself. Interview with Carl B. Rubin, supra note 72. Judge Diskin was pleased by the approach, and the judges got together at the state courthouse to plan coordination which culminated in a fruitful partnership. Id. Similarly, Judges Holland and Shortell were not previously acquainted, yet were receptive to the idea of working together.

203 Judge Fay recalls that during the first conversations, he and Judge DuVal merely "explor[ed] the thought" of coordination. Interview with Peter T. Fay, supra note 100. 
think."204 Although he and Judge Diskin held numerous joint hearings, they generally spoke only once a month.

The methods of communication used also vary from judge to judge and case to case. Whereas some prefered to use the telephone or hold informal meetings im chambers, others maintained contact by mailing or faxing documents such as orders or memoranda to one another.

Whether by phone or fax or im person, ongoing communication can be critical to effective coordination, as illustrated by the experience of Judges Conlon and $O^{\prime}$ Connell. Judge Conlon held monthly status conferences with the federal litigants. A few days before eacl conference, she teleplioned Judge O'Connell to discuss the issues likely to arise during the proceedings and to sliare "off the cuff" innpressions about the cases. ${ }^{205}$ Judge Conlon notes that these conversations lielped lier make "better" decisions. ${ }^{206}$ After the conference, slie would send Judge O'Connell the transcript. The state judge then lield his own conferences, often adopting the procedures arranged in the federal conference. Judge Conlon claims that this arrangeinent discouraged forum sliopping, and lielped produce consistency even without joint liearings and joint rulings. ${ }^{207}$

Maintaining ongoing contact and slaring information yields other benefits as well. Action taken in one court-sucli as settlement or dismissal-can directly affect the tactics of hitigants in the other court's cases. Remaining aware of the course of action in related cases leelps avoid surprises. A situation where a judge is unaware of the action taken by the otlier judge is, according to Judge Rubin, something to "be avoided under any circumstances." 208 To be first informed of such an action by the lawyers wonld "put any judge in a very embarrassing position."209

\section{The Working Relationship}

Those who have engaged in intersystem coordination tend to agree that the strengtli of the personal and working relationship developed between the judges influences the success of the enterprise more than any other factor. As Judge Wemstem puts it: "Coordination lias nothing to do with proce-

204 Interview with Carl B. Rubin, supra note 72.

205 Interview with Suzanne B. Conlon, supra note 196.

206 Id.

207 Id. In the first phase of the New York asbestos litigation, uniform treatment of all parties was a primary concern of Justice Freedınan and Judge Sifton. Interview with Helen E. Freedinan, supra note 75 . They would confer prior to arriving at an opinion or one judge would adopt the outcoine of an issue decided in the other court. Id.

208 Interview with Carl B. Rubin, supra note 72.

209 Id. 
dures; it has to do with personality."210 A number of important dimensions of this relationship can be highlighted. Successful coordination requires flexibility and willingness to compromise $\mathrm{m}$ order to develop arrangements acceptable to both courts. Judge Zampano explains that an "exchange of communication, discussion, and camaraderie is very important. . . . There can't be egos here."211 His collaborator Judge Meadow agrees, adding that coordination requires "two judges that are not going to in any way let their personalities get in the way of their objectives."212 Judge Bechtle suggests that state and federal judges trying to develop a supportive relationship need to take into account "[s]ome degree of informality" as well as "more diplomacy and more consideration and more public relations and courtesy."213 Judge Rubin also stresses the need for informality. ${ }^{214}$ A true partnership cannot emerge unless the judges feel coinfortable with one another and let down barriers.

Coordination also requires mutual respect. Judge Meadow observes that the respect he and Judge Zampano had for each other made their successful collaboration possible: 'I'm sure that [Judge Zainpano] respected what I said and I certainly respected what he said, so we were ... a good team."215

\section{The Role of Attorneys}

Coordination obviously requires that each judge learn of related cases pending in the other court system. Attorneys can be helpful in that regard because they often have related cases pending im both court systems and generally favor intersystem coordination because it can spare them and their clients unnecessary costs and duphication of effort. ${ }^{216}$ Judge Lambros maintains that attorneys are "the best source of information as to the pendency of a state or federal related case" and proposes a rule requiring them to notify

210 Interview with Jack B. Weinstein, supra note 75.

211 Interview with Robert C. Zampano, supra note 106.

212 Interview with Frank S. Meadow, supra note 113.

213 Interview with Louis C. Bechtle, supra note 107.

214 Judge Rubin recalls that at first he and Judge Diskin were tentative about coordination, but "as time went on ... we got to be quite friendly and stopped being Judge Diskin and Judge Rubin and became John and Carl. And that helped." Interview with Carl B. Rubin, supra note 72.

215 Interview with Frank S. Meadow, supra note 113.

216 Judge Shortell reports that there was "never any reluctance on the part of the parties" to bring together the judges handling the Exxon-Valdez hitigation. Interview with Brian C. Shortell, supra note 158. Similarly, Judge Fay recalls that, in the Florida Everglades litigation, "it was ... clear that there was going to be a lot of duplicated effort and cost and the lawyers were obviously willing to do anything they could to streamline it." Interview with Peter $T$. Fay, supra note 100 . 
the court of such cases. ${ }^{217}$ In the cases we studied, however, the attorneys notified the court on their own. ${ }^{218}$

The role of attorneys in state-federal coordination extends beyond getting it started. Their active participation is vital at every stage of coordination. Attorneys may be inore knowledgeable than the court about numerous matters relevant to coordination, such as relationships among counsel, parties' different priorities and stages of preparation, or ongoing settleinent talks. Furthermore, because the judiciary has limited experience with intersystem coordination, attorneys are a welcoine source of ideas. One commentator observes the tendency to "underestimate the power of counsel in fashioning procedural decisions and the role of counsel as a natural constituency for both federal and state judges." 219

Coordination requires not only that attorneys commumicate with the court, but also cooperate with one another. ${ }^{220}$ This is partly because "[a] bar that is collegial and cooperative will foster joint activity by judges,"221 but also because the actual state-federal arrangements often involve committees of attorneys taking the lead in achieving intersystem coordination.

Although attorneys may decide to work together without court supervision, judges need not rely on such imitiative-they may appoint a limited number of attorneys to supervise state-federal efforts. In the New York asbestos cases, the first step toward coordination was Justice Freedinan's appointment of the same haison counsel to handle the state cases as Judge Sifton had already appointed for the federal cases. ${ }^{222}$ Similarly, in the Florida Everglades hitigation, Judge Fay imitially appointed a "plamtiffs' committee" to coordinate discovery in the federal court and Judge DuVal later appointed the same attorneys as lead counsel in the state cases. In the Hyatt

217 Interview with Thomas D. Lambros, supra note 75.

218 Justice Freedman recalls that in the Brooklyn Navy Yard litigation the attorneys in both the state and federal cases brought her a copy of Judge Sifton's asbestos litigation case management plan. Interview with Helen E. Freedman, supra note 75 . Judge Fay remembers that within weeks of the filing in his court of the Florida Everglades cases, attorneys informed him of related cases in state court. Interview with Peter T. Fay, supra note 100. Likewise, in the Sioux City litigation, attorneys informed Judge Conlon that similar cases were filed in other courts. Interview with Suzanne B. Conlon, supra note 196.

219 McGovern, supra note 197, at 9.

220 Successful coordination in the New York asbestos cases, for example, was largely a function of collegiality among counsel. Justice Freedman notes that the "[1]awyers [had] done depositions upon depositions for years together, so [they] all knew each [otlier]" even before she and Judge Sifton began working together. Interview with Helen E. Freedman, supra note 75.

221 McGovern, supra note 197, at 9.

222 See Meinorandum from Sol Wachtler, Chief Judge New York Court of Appeals, Federal-State Coordination of Asbestos Litigation in New York City (May 1, 1991) (on file with the Federal Judicial Center, Washington, D.C.). 
Skywalk cases, the attorneys with cases in the state court elected a liaison committee to handle discovery in the state cases. ${ }^{223}$ Judges Wright and O'Leary subsequently appointed a "Joint State-Federal Liaison Committee" to coordinate pretrial activities for the state and federal cases. The joint committee consisted of members of the state committee and several others independently appoimted by Judge Wright. ${ }^{224}$ Both judges report that this arrangement worked well. ${ }^{225}$

Harmomous interaction becomes difficult if many attorneys are involved. Early in the Beverly Hills Supper Club hitigation, Judge Rubim appoimted seven attorneys to serve as lead counsel. He later informed Judge Diskin of the appointment, and the state judge similarly appoimted seven attorneys. The fourteen attorneys subsequently formed a joint state-federal steering committee. In retrospect, Judge Rubin beheves the committee was too large. "[P]redictably, there was . . . an internal fight among the lawyers, and one group emerged in control . . . and they proceeded to litigate the case[s] thereafter."226 He believes that a small state-federal lead counsel committee would make dual system cooperation "immensely easier."227

Judge Rubin draws a second lesson from this experience: the value of consultation between state and federal judges before lead counsel is appointed for either ease. He beheves the problem of the oversized joint committee would have been avoided had he discussed the matter with Judge Diskin at the beginning; the two would have agreed on a sinaller number of attorneys to handle the hitigation. ${ }^{228}$ Judges Holland and Shortell put this theory into practice, joimtly reviewing resumes im order to select lead and haison counsel to manage the Exxon-Valdez pretrial proceedings for both courts. The common committee structure has worked well thus far. ${ }^{229}$

Yet, cooperation among attorneys has limits. In the Hyatt Skywalk litigation, the attorneys in federal court preferred a class action while the attorneys in the state cases wanted to handle their cases individually, ${ }^{230}$ and considerable tension resulted. In general, lawyers favor state-federal coordi-

223 See Wright \& Colussi, supra note 58, at 164.

224 Further, the judges requested that this committee develop a "comprehensive plan for discovery ... [and] prepare briefs on common issues in pre-trial discovery inatters." Memorandum and Order at 4, In re Federal Skywalk Cases (No. 81-0593-CV-W-3) (W.D. Mo. Sept. 2, 1981) (establishing Joint State-Federal Liaison Committee and its obligations).

225 Interview with Scott O. Wright, supra note 182; Interview with Timothy O'Leary, supra note 94 .

226 Interview with Carl B. Rubin, supra note 72.

227 Id.

228 Id.

229 Interview with $\mathrm{H}$. Russel Holland, supra note 74.

230 The state plaintiffs tended to have more serious imjuries than their federal counterparts and thought they were better off without class certification, whereas federal plaintiffs were 
nation of discovery and settlement, but are sometimes reluctant to proceed further because they have consciously chosen to proceed in one forum, and do not want to see the significance of that decision diminished. Courts should be sensitive to their interests and seek the lawyers' approval (not merely their grudging acceptance) of such intersystem coordination as secms desirable. This may imvolve assuring counsel that even when matters are jomtly briefed, argued, and even decided, the judge in whose court the case is brought will not abdicate his or her responsibility to give the matter independent consideration.

\section{E. Situations Most Conducive to Effective Coordination}

Most coordination has occurred in hitigation arising out of a single, discrete event. Although such cases are typically the best candidates for coordination, they are not the ouly ones. Indeed, in both the Ohio and New York asbestos cases, the hitigation ranged far beyond a single event. Whenever there are closely related cases im the state and federal courts, intersystem coordination is a possibility worth exploring. There are, however, certain circumstances under which coordination has proven most feasible.

\section{Proximity}

Not surprisingly, judges have found that coordination works best when the state and federal courts are in close proximity. ${ }^{231}$ In an effort to coordinate all asbestos-related cases filed in the New York federal courts, Judge Weinstein contacted the chief judges of all the federal districts. The Eastern and Southern Districts, each with courts located in New York City, arranged to consolidate their cases before one judge, whereas coordination was not achieved with the Western and Northern Districts. Judge Weinstein beheves that the geographical distance between the New York City judges and the upstate judges prevented the "meeting of the minds" that was achieved by the courts located in New York City alone. ${ }^{232}$ The effect of distance is also observable in the Sioux City cases. Judges Conlon and O'Counell, both located in Chicago, maintained frequent contact and

primarily concerned about the distribution of punitive damages and thus favored a class action. Interview with Timothy D. O'Leary, supra note 94.

231 This is not to say, however, that more extensive coordination with a distant court can never be achieved. In the Chicago air crash hitigation, the federal cases were consolidated pursuant to 28 U.S.C. $\S 1407$ and assigned to judges in Chicago, whereas a large cluster of cases was filed in a California state court. See In re Airline Disaster Litig. Report, 127 F.R.D. 405, 406 (N.D. Ill. 1988). The federal and state courts coordinated discovery to some extent, although the cooperation achieved in this ease was not nearly so great as that achieved in cases where the state and federal courts were in greater proximity.

232 Interview with Jack B. Weinstein, supra note 75. 
engaged in extensive coordination. Although Judge Conlon also faxed copies of her orders to a Missouri state judge handling related cases, no further coordination was achieved with this judge.

The JPML recognizes the relevance of geographical proximity to statefederal cooperation. In several cases, it has cited potential intersystem coordination as a reason for transferring cases to a particular district. In the Sioux City eases, for example, the JPML observed that "numerous related actions are pending in Illinois state court" and correctly predicted that "transfer to the Northern District of Illinois could facilitate coordination among the federal and Illinois state court actions."233 In another litigation, the JPML, in transferring several federal cases to the Eastern District of New York, noted that "related litigation is pending in the New York state courts, thus enhancing the opportunity for state/federal coordination."234

\section{Intrasystem Aggregation}

The possibility of intersystem coordination is enhanced when the cases within each systein are aggregated. When one judge is in charge of all the cases in a systein, that judge can structure the hitigation and ensure uniform treatinent of the cases. This, in turn, makes it possible to develop a coherent plan for coordinating related cases with another court. The collaborative process is obviously easier when there are fewer judges involved. Such things as coordinated scheduling, a common case inanagement plan, and joint hearings require extensive effort and communication between two judges and become far more difficult as the number of judges increases. Moreover, when only a few judges inanage all of the related cases, these judges have access to all of the parties and thus an opportunity to encourage a global settleinent, which would be far less likely if the cases were scattered among inany courts. In all of the cases studied, soine form of aggregation was achieved within both the state and federal systems.

The JPML recognizes that intrasystem aggregation greatly facilitates intersystem coordination. When transferring 26,000 asbestos cases to the

233 In re Air Crash Disaster at Sioux City, Iowa, on July 19, 1969, 128 F.R.D. 131, 132-33 (J.P.M.L. 1989).

234 In re Ambassador Group Inc. Litig., Docket No. 778, 1988 U.S. Dist. LEXIS 17024, at *3 (J.P.M.L. October 12, 1988) (transfer order). See also In re Oil Spill By "Amoco Cadiz," 471 F. Supp. 473, 478-79 (J.P.M.L. 1979) (noting related actions pending in Illinois state court and stating that the "possibility of promoting this state/federal coordination is another factor favoring the selection of the Northern District of Illinois as the transferee forum"); In re Air Crash Disaster at Florida Everglades on December 29, 1972, 360 F. Supp. 1394, 1395-96 (J.P.M.L. 1973) (noting state-federal coordination that had already taken place and finding that " $[t]$ ransfer of all actions to the Southern District of Florida, therefore, will take advantage of this state-federal accommodation .... and will greatly enhance the expeditious processing of all actions arising out of the crash"). 
Eastern District of Pennsylvania, the JPML noted that "transfer will . . . have the salutary effect of creating one federal court with which [state] proceedings can be coordinated ... . Indeed, state court judges have communicated to the Panel that coordination among state courts and a single transferee court for the federal actions is an objective worthy of pursuit."235

\section{A Supportive Legal Community}

Although the actual state-federal coordination usually involves the work of a few individual judges, the appropriate judicial environment throughout a jurisdiction can facilitate coordination. For exaniple, Judge Shortell describes the Alaska court systems as "more relaxed" than those in larger jurisdictious such that "[t]here is not so inuch formality" and certainly no "friction" between the state and federal courts. ${ }^{236}$ Because of this, he says, "there is no innediment . . . even to [judges] who don't know each other, getting together and talking [about their cases]."237 Similarly, Judge Zampano beheves that his coordination with Judge Meadow was aided by the nature of Connecticut's judicial community in which the courts "have comity beyond the everyday business."238

The larger legal community made a similar contribution to the coordination achieved in the New York asbestos hitigation. After Justice Freedman contacted Judge Sifton about the possibility of coordination, the two judges inet with Judge Weinstein, then Chief Judge of the Eastern District of New York, and the Hon. Xavier C. Riccobono, Administrative Judge of the Civil Branch of the State Supreme Court of New York County. The four judges explored ways for the two courts to cooperate. The participation of Judges

235 In re Asbestos Prod. Liab. Litig., 771 F. Supp. 415, 421 n.6 (J.P.M.L. 1991). In affirming an order staying an action pending in California on the grounds of forum non conveniens, a state appellate court recognized that:

[H] undreds of suits resulting from the fire have been filed in Nevada in federal or state court and a massive consolidation effort has been ongoing in these courts for over a year. A huge amount of discovery has already occurred and the documents are stored in a Las Vegas warehouse, available to inspection by all parties in both state or federal actious. Additionally, nuch preliminary pleading and law and motion work has taken place in Nevada courts. In view of the advanced stage of this consolidated hitigation, it is certainly in the best interests of judicial efficiency to require the plaintiffs to file in Nevada since the litigation process there is already well underway.

Dendy v. MGM Grand Hotels, Inc., 187 Cal. Rptr. 95, 98-99 (Ct. App. 1982). When the bulk of hitigation is proceeding in one locale, and state and federal judges within that locale are coordinating their cases, judges from other areas should consider limiting access to their own fora in order to facilitate the coordination. In the MGM hitigation, Judge Bechtle's and Judge Thoinpson's coordination encouraged courts of other states to stay their proceedings.

236 Interview with Brian C. Shortell, supra note 158.

237 Id.

238 Interview with Robert C. Zampano, supra note 106. 
Weinstein and Riccobono conveyed an important inessage: Justice FreedInan and Judge Sifton knew that their courts endorsed state-federal judicial coordination. ${ }^{239}$

Because an atınosphere in which state and federal judges feel comfortable conferring and collaborating with one another can facilitate coordination, judges (especially chief judges) attracted to the possibility of intersystein coordination inay wish to consider how to foster such an atmosphere. ${ }^{240}$

\section{F. Federalism Concerns}

The potential benefits of intersystem coordination should be clear. There are, however, potential drawbacks as well, inostly stemming froin the fact that intersystein coordination invites tampering with the traditional jurisdictional boundaries of the state and federal court systems. The United States Constitution envisions two separate judiciaries. ${ }^{241}$ For the country at large, this division provides varied laboratories in which to test different approaches. For individual hitigants dual judiciaries can offer a choice of where to pursue or defend against a claim. Judges nuust be sensitive to the possibility that state-federal coordination can undermine these interests.

\section{Shared Power Relationship}

Coordination requires judges to make joint decisions involving both case manageinent and legal interpretation. Certain risks inhere in any joint decisionmaking situation. First, the necessary coinpromises will, in the perception of an individual judge, sonietimies conte at the expense of excellence. There nuay be situations - especially on nondispositive matters such as discovery arrangenients-where a judge feels that acting consistently with the other court is more miportant than issuing what he or she considers to be a perfect ruling. Judges should exercise care not to coinpromise too much. Where the ruling affects the substantive rights of the parties, judges should generally adopt what they consider to be the proper ruling, ${ }^{242}$ even if it produces an inconsistency with the other court.

Another potential problem with any power-sharing arrangement is that one party may exert too much influence. As a result, the inethods and interpretations of the subordinate partner are lost. Put differently, when one

239 Since the Brooklyn Navy Yard hitigation, New York state and federal judges have cooperated in pretrial and settlement efforts for other clusters of cases. See Memorandum, supra note 222.

240 In addition to those circumstances discussed in this Section, the ability to coordinate effectively can vary according to the nature of the substantive legal disputes. See, e.g., McGovern, supra note 197, at 4.

241 U.S. Const. arts. III, IV.

242 See infra text accompanying notes 251-66 (discussing deference). 
judge takes a dominant role, a fuller range of approaches may be sacrificed. ${ }^{243}$ In addition, judges risk diminishing the integrity of their court's decisionmaking process if they become a rubber stamp for another court. In several of the cases under study, one judge essentially controlled the litigation in both systems. ${ }^{244}$ It was not uncommon for the federal court to play this role. ${ }^{245}$ In hight of federal courts' greater resources, this tendency is understandable, but judges should take care that dominance be avoided if possible. In addition to the risks described, federal courts should be wary of overstepping their Article III function by inaking decisions affecting persons over whom they have no jurisdiction. ${ }^{246}$

\section{Litigant Choice}

Perhaps the greatest concern is that intersystem coordination can diminish the hitigants' benefits of their choice of forum. They might have had good reason for selecting one court system over the other, ${ }^{247}$ and when judges work together and influence one another, or mold their rules to conform to those of another system, or decide matters jointly, litigants may lose the advantages of their cliosen forum. ${ }^{248}$

243 The potential for sacrificing one court's practices and views is especially acute because state and federal judges have different experiences and occupy different institutional positions. There is the risk, for example, that federal courts will interfere unduly with the development of state law. See infra text accompanying notes 260-65 (addressing federal court deference on questions of state law).

244 In some cases, one judge dominated pretrial case management. See discussion of Florida Everglades hitigation, supra p. 1700 . In other cases, one judge proceeded to trial whercas the other judge in effect stayed his or her proceedings. See discussion of MGM Hotel litigation, supra note 103 and accompanying text.

245 Of course, one factor to be considered is how cases end up in different courts. For example, in the MGM litigation, most cases were in the federal court under diversity jurisdiction, with the state cases filed as "savings" cases should something happen to the federal claims. See Interview with J. Charles Thompson, supra note 73. A federal lead was perhaps more justifiable in this situation tlian in the Hyatt Skywalk litigation where the majority of cases was filed in state court.

246 See In re Allied Signal, Inc., 915 F.2d 190, 191 (6th Cir. 1990) ("Unless Congress has granted jurisdiction to the courts, Article III limits the ability of district courts to act.").

247 See Note, Forum Shopping Reconsidered, 103 Harv. L. Rev. 1677, 1678-79 (1990).

Among the considerations that may motivate a forum shopper are the convenience or expense of hitigating in the forum, the inconvenience to one's adversary, the probable or expected sympathies of a potential jury pool, the nature and availability of appellate review, judicial calendars and backlogs, local rules, permissibility of fee-splitting Id. arrangements, and virtually any other interjurisdictional difference.

248 In addition, when judges work together they may upset the traditional modus operandi that exists within a court system. For example, attorueys may feel less able to challenge a ruling or arrangement agreed to by two judges. 
Nevertheless, the judicial system need not be hostage to all party preferences. For example, defendants in mass hitigation sometimes prefer delay because it can inake plaintiffs more willing to settle for a lesser amount. But the judiciary generally does not consider delay a value worth protecting, ${ }^{249}$ and if state-federal coordination denies a party desired delay, that can hardly be considered problematic. Judge Fay goes further in downplaying concern that intersystein coordination demes hitigant choice:

Everyone has to have access to the courts.... [But i]f they come im, they are bound by all types of restrictive procedures .... There [are] a lot of things they can do. There [are] a lot of things they can't do. It is a question of weighing the rights of the individual, weighing the due process that everyone is entitled to ... and trying to accommodate all that in an efficient way. ${ }^{250}$

Although state-federal coordination inay deprive some parties of the benefits of their chosen forum, that price may be worth the gams to the entire judicial system. Nevertheless, there is a trade-off, and courts should keep sight of the costs.

The potential problem of state-federal coordination denying litigants full and independent consideration within their forum is perhaps most acute where state and federal courts join forces in deciding issues of substantive law. We now turn our attention to that area.

\section{Deference on Substantive Law Issues}

The state and federal judicial systems have traditionally apphied each other's law. Federal courts address state law questions in diversity cases and state courts have concurrent jurisdiction over most federal causes of action. Not everyone finds this overlap felicitous. Some argue that the expertise and constitutional independence of federal judges inake them far better equipped than their state counterparts to apply federal law. ${ }^{251}$ Conversely, some mamtain that federal judges lack the expertise and interest necessary to

249 See Fed. R. Civ. P. 1 ("These rules ... shall be construed to secure the just, speedy, and inexpensive determination of every action.").

250 Interview with Peter T. Fay, supra note 100.

25l See, e.g., Akhil R. Amar, A Neo-Federalist View of Article III: Separating the Two Tiers of Federal Jurisdiction, 65 B.U. L. Rev. 205, 235-38 (1985). Article III of the United States Constitution confers on federal judges lifetime tenure and prohibits diminution of their conıpensation. According to Professor Amar, these privileges insulate federal judges from political pressures and therefore make them better guardians of individual rights and the national interest than their state counterparts. 
apply state law effectively. ${ }^{252}$ Each of these perspectives, of course, has a counterperspective, e.g., the value of fifty laboratories in which approaches to federal law can be tested, and the need for a federal forum to protect nonresidents froin local prejudice.

These concerns are especially germane when state and federal judges coordinate their related cases. The inost pressing issues are whether federal and state courts should defer to one another on questions of state law and federal law respectively. On its face, it would secm that substantive law disputes provide state and federal courts with an opportunity to benefit from inutual assistance: the state court can follow the federal court's lead on inatters of federal law and vice versa. In fact, the inatter is more coinplex. Fortunately, courts are not without guidance in addressing these questions because they arise not only in coordinated state-federal hitigation but in other situations as well.

\section{a. State Court Deference on Questions of Federal Law}

The overwhelming inajority of state courts to address the question have held that they are not bound by lower federal court decisions on federal law. ${ }^{253}$ One commentator expresses and endorses the prevailing view as follows:

In cases in which federal law is applied, and the jurisdiction in federal and state courts is concurrent, the state court inust follow the federal law, and the decisions of the inferior court are, naturally, persuasive authority on issues as yet unresolved by the Supreme Court. In such cases, however, the state courts owe no special obedience to the decisions of the particular circuit in which the state is located, or in the strict sense, to the decisions of the federal inferior courts as a class, and any error they inay make in their imterpretation of the federal law must be corrected by the Supreme Court. ${ }^{254}$

252 See, e.g., Robert H. Bork, Dealing with the Overload in Article III Courts, 70 F.R.D. 231, 237 (1976) (noting that federal courts lack familiarity with the application of state law and are especially disadvantaged where the contested point is not settled).

253 No one questions that the Supreme Court's decisions on issues of federal law are binding on all state and federal courts.

254 1B James W. Moore, Jo D. Lucas \& Thomas S. Currier, Moore's Federal Practice If 0.402[1] at n.40 (2d ed. 1992). See also Robert M. Cover \& T. Alexander Aleinikoff, Dialeetical Federalisin: Habeas Corpus and the Court, 86 Yale L.J. 1035, 1053 (1977) (noting that "[c]learly, state courts are not bound to respeet the doctrinal stateinents of the inferior federal tribunals insofar as they understand those stateinents not to be compelled by the Supreme Court"); Daniel J. Meltzer, State Court Forfeitures of Federal Rights, 99 Harv. L. Rev. 1128, 1231 n.495 (1986) ("Decisions of lower federal courts on issues of federal law are not binding precedents for a state court . ..."); David L. Shapiro, State Courts and Federal Declaratory Judgments, 74 Nw. U. L. Rev. 759, 771 (1979) (“[O]nly the Supreine Court sits 
If this view is correct, it would be problematic for a state court, in the course of coordimating companion cases with a federal court, simply to cede the imterpretation of federal law to the federal court. In doing so, the state court would appear to be abdicating its responsibility to the litigants before it. ${ }^{255}$

There is a school of thought, however, that state courts are bound by federal court decisions on federal law. This argument rests on federal courts' expertise in federal law and the value of uniformity. In dicta the Nimth Circuit recently said:

Having chosen to create the lower federal courts, Congress may have intended that just as state courts have the final word on questions of state law, the federal courts ought to have the final word on questions of federal law. The contrary view could lead to considerable friction between the state and federal courts as well as duphicative itigation. 256

The court, therefore, expressed "serious doubts" about the proposition that "state courts are free to ignore deeisions" of the lower federal courts. ${ }^{257}$

Significantly, the Ninth Circuit's language suggests a false dichotomy between state courts either being bound by or ignoring lower federal courts' decisions on federal law. In fact, state courts almost invariably acknowledge that federal courts' interpretations of federal law warrant respect and consideration. Some have recognized policy reasons for following the federal circuit court within whose boundaries they reside, while noting that they are not bound to do so. ${ }^{258}$ Other state courts have found that federal court deci-

atop the state courts in the national hierarchy."); Note, Authority in State Courts of Lower Federal Court Decisions on National Law, 48 Colum. L. Rev. 943, 945 (1948) (noting the refusal of inany state courts to follow lower federal court decisions). The two federal circuit courts to decide this issue agree. United States ex rel Lawrence v. Woods, 432 F.2d 1072, 1075 (7th Cir. 1970), cert. denied, 402 U.S. 983 (1971); Owsley v. Peyton, 352 F.2d 804, 805 (4th Cir. 1965). This view derives from the parallel structure of the two systems where federal law is concerned: the state courts and lower federal courts have concurrent jurisdiction; neither has appellate power over the other; and the Umited States Supreme Court has appellate power over both.

255 See State v. Colenian, 214 A.2d 393, 404 (N.J. 1965) (observing that to blindly follow the federal courts would be to "abdicat[e] our undoubted responsibility to pass on issues of constitutionality and justice as we see them"), cert. denied, 383 U.S. 950 (1966).

256 Yniguez v. Arizona, 939 F.2d 727, 736 (9th Cir. 1991).

257 Id.

258 See State v. Goodell, 734 P.2d 10, 11 (Or. App. 1987) ("[The Ninth Circuit's] decision is controlling on the federal courts in Oregon, and there are practical advantages, which we cannot ignore, when federal and state courts adopt the same interpretation of federal law."), review denied, 734 P.2d 1248 (Or. 1987); Pennsylvania v. Negri, 213 A.2d 670, 672 (Pa. 1965) ("If the Peunsylvania courts refuse to abide by [the Third Circuit's] conclusions, then the individual to whoin we deny relief need only to 'walk across the street' to gain a different result. Such an unfortunate situation would cause disrespect for the law."). 
sions are entitled to special weight, even though they are not binding, when there is a strongly prevailing view in the federal courts. ${ }^{259}$

This middle path offers a fruitful possibility to federal and state courts coordinating their coinpanion cases: although the state court should not autoinatically follow the federal court's determinations on federal law, it inay accord thein great weight, perhaps even a rebuttable presumption of correctness. This policy of deference would seein especially justified in liglit of the value of producing consistent results in related cases. As long as the deference is not blind, the state court arguably fulfills its responsibility.

\section{b. Federal Court Deference on Questions of State Law}

It is well settled that state courts are the higliest autliority in the interpretation of their own law. Therefore, wlien a federal court faces a question of state law, it inust follow the interpretation of that state's highest court. ${ }^{260}$ In cases where the state's highest court has not addressed the issue, the federal court must predict what the state court would do. ${ }^{261}$ Whereas decisions of the state's highest court are binding, federal courts are not bound by lower state courts' interpretation of state law. ${ }^{262}$ Thus, when state and federal courts coordinate their related cases, it may be problematic for the federal

259 See, e.g., Edwards v. Henry, 293 N.W.2d 756, 759 (Mich. App. 1980) ("[W]here there exists no split of authority in the Federal courts concerning the interpretation of a Federal statute, state courts should be very cautious in differing with the prevailing view in that system ....."); Wimberly v. Labor and Indus. Relations Comm'n, 688 S.W.2d 344 (Mo. 1985) (en banc), aff'd, 479 U.S. 511 (1987).

[The lower court] stated that the courts of this state, when confronted with the task of interpreting a federal statute, are bound to follow the decisions of lower federal courts construing the statute in question. ... [T] [Tis court has never subscribed to such a notion. On the contrary, we have adhered to the view that the courts of this state are bound to follow only our Supreine Court's decisions interpreting the federal Constitution and federal statutes. ... .

... [But] in soine circumstances it may be appropriate for a state court to defer to long established and widely accepted federal court interpretatious of federal statutes.

Id. at 347-48. See also Blankenship v. Union Pac. R.R. Co., 742 P.2d 680, 681-82 (Or. App. 1987), review denied, 749 P.2d 136 (Or. 1988).

There is no controlling United States or Oregon Suprene Court decision on the question. That being so, it is clearly within the authority of this court to adopt either position on the federal question, and we are not bound by what the inajority of federal (or state) courts have held. [But] it is also clear that, in deciding what the federal law is, the fact that a decided preponderance of federal courts have taken one view rather than the other is a relevant consideration in itself, along with but independently of the persuasiveness of the reasoning which supports the two views.

Id. (einphasis onitted).

260 See Erie R.R. v. Toinpkins, 304 U.S. 64, 78 (1938).

261 See, e.g., In re Kirkland, 915 F.2d 1236, 1239 (9th Cir. 1990).

262 Commissioner v. Estate of Bosch, 387 U.S. 456, 465 (1967). 
court simply to adopt the state court's rulings on state law. ${ }^{263}$ If federal litigants argue that the state's highest court would probably rule otherwise, they may be entitled to have the argument considered by the federal court.

Once again, though, the choice is not between blindly following a court's interpretation and iguoring it. Indeed, it is settled doctrine that the decisions of lower state courts on matters of state law, although not binding on federal courts, carry significant weight. ${ }^{264}$ In the context of companion state-federal cases, the value of consistency arguably justifies the federal court giving the state court's imterpretation of state law even more weight than it otherwise might-albeit still making sure that it regards the state court's interpretation as reasonable. This also ensures that the federal court does not excessively interfere with the development of state law. ${ }^{265}$

In this discussion, we do not purport to resolve the issues raised. Rather, we emphasize that state and federal courts coordinating their cases must be aware of and sensitive to these issues. We have suggested possible ways of approaching these matters, ways that neither tliwart extensive coordination nor lead courts to take actions that might be construed as an abdication of their respective responsibilities. ${ }^{266}$

\section{Conclusion}

The cases we have studied tell stories of how state and federal judges broke new ground leading to better justice in complex parallel litigation in the two court systems. These experiences are instructive for judges im other cases, not so much by disclosing specific techiniques or methods (although those can be helpful), but rather by illustrating what can be done, stimulat-

263 Where the issue is significant, and state law permits, the federal court may stay its hearings while the disputed question is certified to a higher state court for decision. Lehman Bros. v. Schein, 416 U.S. 386, 389-91 (1974).

264 See Estate of Bosch, 387 U.S. at 465 (noting that federal court must give "proper regard" to decisions of lower state courts).

265 In the cases studied, the state court judges were careful not to take a back seat on questions of state law. For example, whereas Judge Bechtle took the lead in the MGM litigation, Judge Thompson made sure that interpretation of state law was correct. He says that "I'm basically a states' rights guy. I'm interested in seeing that the people of Nevada are protected. Judge Bechtle is from Philadelphia. He doesn't know anything about Nevada law. Is he the best one to decide how Nevada law should be construed?" Interview witll J. Charles Thompson, supra note 73 .

266 We do not suggest that intersystem coordination has caused inajor complications thus far. In fact, it appears not to have done so: the cases have given rise to few appeals. Judge Thompson notes that "I [had] no appeals from any of my orders to the Supreme Court of Nevada. The lawyers were happy with the process." Interview with J. Charles Thompson, supra note 73. Similarly, Judge Shortell reports that "[t] here was no question raised [about authority]." Interview with Brian C. Shortell, supra note 158. 
ing ingenuity and initiative, alerting judges to potential opportunities and pitfalls, and encouraging them to take risks in the interest of achieving gains.

These stories demonstrate that pursuing state-federal coordination is no easy task. The participants in the process are doing nothing less than, as Judge Lanbros describes it, creating a new cultural setting for litigation. ${ }^{267}$ It requires hard work and commitinent, iniagination and diplomacy, and persistence teinpered by flexibility (and cannot be left to others-early action by judges is necessary lest opportunities be missed). The potential rewards, however, are high. State-federal coordination-even if it falls short-can pay off in furthering economy, efficiency, and fairness in the hitigation process and in proinoting settleinents.

What judges have done in these cases replicates the history of the common law: finding ways around the systern's constraints and encumbrances to achieve equity. And although this paper focuses on large scale hitigation, coordination in sinall cases inay be useful as well. Opportunities for such coordination and cooperation, once they are recognized, abound. Judges could coordinate where attorneys claim calendar conflicts. They could clarify the unpact of bankruptcy stays, a common source of cross-system irritation. They could perhaps coordmate to ease the inipact of rulings on habeas corpus petitions. To further these steps, State-Federal Judicial Councils could adopt protocols that set up procedures for judges to inake contact, commumicate, and inipleinent various coordination techinques. ${ }^{268}$ These councils and individual state and federal judges should give thought to new areas in which intersystem cooperation inay be useful.

Coordination can be proinoted if judges are advised of related cases, no inatter how sinall, pending in the other systein. Attorneys will not always perforn this function unless prompted. Pending related cases inight, therefore, be added to the hist of subjects for pretrial conferences by amendinent of Federal Rules of Civil Procedure 16 and state rules of procedure. ${ }^{269}$ Federal and state rules of procedure might further be amended to specifically provide authority to judges to coordinate proceedings across state and federal lines. The adoption of protocols or rules, however, should be inforined by the need for flexibility to adjust to the deinands of particular litigation: the personalities of the participants, the kinds of substantive and procedural issues involved, and the gains to be achieved weighed against the costs of

267 See supra text accompanying note 139.

268 The Florida State-Federal Judicial Council already has in place a procedure for handling situations in which attorneys are scheduled to appear in state and federal court at the same time. See Resolution of the Florida State-Federal Judicial Council Regarding Calendar Conflicts Between State and Federal Courts (January 26, 1985).

269 The rules could simply authorize state-federal coordination generally or could authorize an elaborate system of procedures governing imtersystein arrangements. 
coordination. They should not stifle ingenuity and initiative. And they should not obscure the iniportance of hittle things on which to build the requisite collegial relationship between state and federal judges.

State-federal cooperation can give new meaning to judicial federalisin, turning it froin a wall into a thoroughfare to better justice. Of walls, Robert Frost once asked:

Why do they make good neighbors? Isn't it

Where there are cows? But here there are no cows.

Before I built a wall I'd ask to know

What I was walling in or walling out $\ldots . .^{270}$

270 Robert Frost, Mending Wall, in The Poetry of Robert Frost 33 (Edward C. Lathem ed., 1969). 
HeinOnline -- 78 Va. L. Rev. 17521992 